\title{
Regulation of Resistance in Vancomycin-Resistant Enterococci: The VanRS Two-Component System
}

\author{
Alexandra A. Guffey and Patrick J. Loll *(D) \\ Department of Biochemistry \& Molecular Biology, College of Medicine, Drexel University, \\ Philadelphia, PA 19102, USA; alexguffey9@gmail.com \\ * Correspondence: pj128@drexel.edu
}

check for updates

Citation: Guffey, A.A.; Loll, P.J.

Regulation of Resistance in

Vancomycin-Resistant Enterococci: The VanRS Two-Component System. Microorganisms 2021, 9, 2026.

https://doi.org/10.3390/

microorganisms 9102026

Academic Editor: Kirsten Jung

Received: 30 August 2021

Accepted: 22 September 2021

Published: 25 September 2021

Publisher's Note: MDPI stays neutral with regard to jurisdictional claims in published maps and institutional affiliations.

Copyright: (c) 2021 by the authors. Licensee MDPI, Basel, Switzerland. This article is an open access article distributed under the terms and conditions of the Creative Commons Attribution (CC BY) license (https:// creativecommons.org/licenses/by/ $4.0 /)$.

\begin{abstract}
Vancomycin-resistant enterococci (VRE) are a serious threat to human health, with few treatment options being available. New therapeutics are urgently needed to relieve the health and economic burdens presented by VRE. A potential target for new therapeutics is the VanRS twocomponent system, which regulates the expression of vancomycin resistance in VRE. VanS is a sensor histidine kinase that detects vancomycin and in turn activates VanR; VanR is a response regulator that, when activated, directs expression of vancomycin-resistance genes. This review of VanRS examines how the expression of vancomycin resistance is regulated, and provides an update on one of the field's most pressing questions: How does VanS sense vancomycin?
\end{abstract}

Keywords: vancomycin; antibiotic resistance; two-component system

\section{Introduction}

In the early 1950s, the glycopeptide vancomycin was isolated from Amycolatopsis orientalis and soon emerged as a promising new treatment for infections caused by penicillinresistant staphylococci and other Gram-positive bacteria [1,2]. Early studies showed that the compound successfully cleared staphylococcal infections and did not induce resistance in serial-passaging experiments $[1,3,4]$. Thus, vancomycin was greeted as an attractive alternative to penicillin and was swiftly approved for clinical use by the U.S. Food and Drug Administration in 1958 [1,5,6]. Impurities present in early vancomycin preparations gave rise to significant toxicity, but improved formulations overcame most of these issues; nonetheless, perceptions about toxicity lingered [1,7]. At the same time, alternatives became available (e.g., methicillin), and as a result vancomycin was used only sparingly until the early 1980s, when the increasing prevalence of methicillin-resistant $S$. aureus prompted its use as an antibiotic of last resort [8-12]. Vancomycin also became a popular treatment option for enterococcal infections, which are tolerant of or resistant to some other antibiotic classes $[13,14]$. This increased use of vancomycin encouraged the development and spread of vancomycin-resistant enterococci (VRE).

VRE infection was first identified as an emerging clinical problem in the late 1980s, nearly 30 years after vancomycin made its debut $[15,16]$. Today, VRE are recognized as a pressing clinical concern [17-19]. Vancomycin-resistant E. faecium is listed among the so-called ESKAPE pathogens (E. faecium, S. aureus, K. pneumoniae, A. baumannii, P. aeruginosa, and Enterobacter spp.) [20], and the World Health Organization has also identified VRE as a high priority for the development of new antibiotics [21]. VRE levels continue to increase, and the prevalence of VRE infections-nearly 55,000 cases reported in the US alone in 2017-emphasizes the need for a deeper understanding of how VRE function [22-24]. An important aspect of VRE pathology is the regulatory system that controls expression of the resistance phenotype; this review aims to provide an update on the molecular mechanisms by which vancomycin resistance is regulated in enterococci. 


\section{Background}

\subsection{Mechanism of Vancomycin Resistance in VRE}

Vancomycin inhibits cell wall synthesis. It does so by binding the D-alanyl-D-alanine (D-Ala-D-Ala) residues of the muramyl pentapeptide portion of lipid II, a precursor in peptidoglycan synthesis (Figure 1) [25-28]. This binding event interferes with crosslinking of the pentapeptide and formation of mature peptidoglycan (Figure 1) [29], ultimately causing osmotic cell lysis.

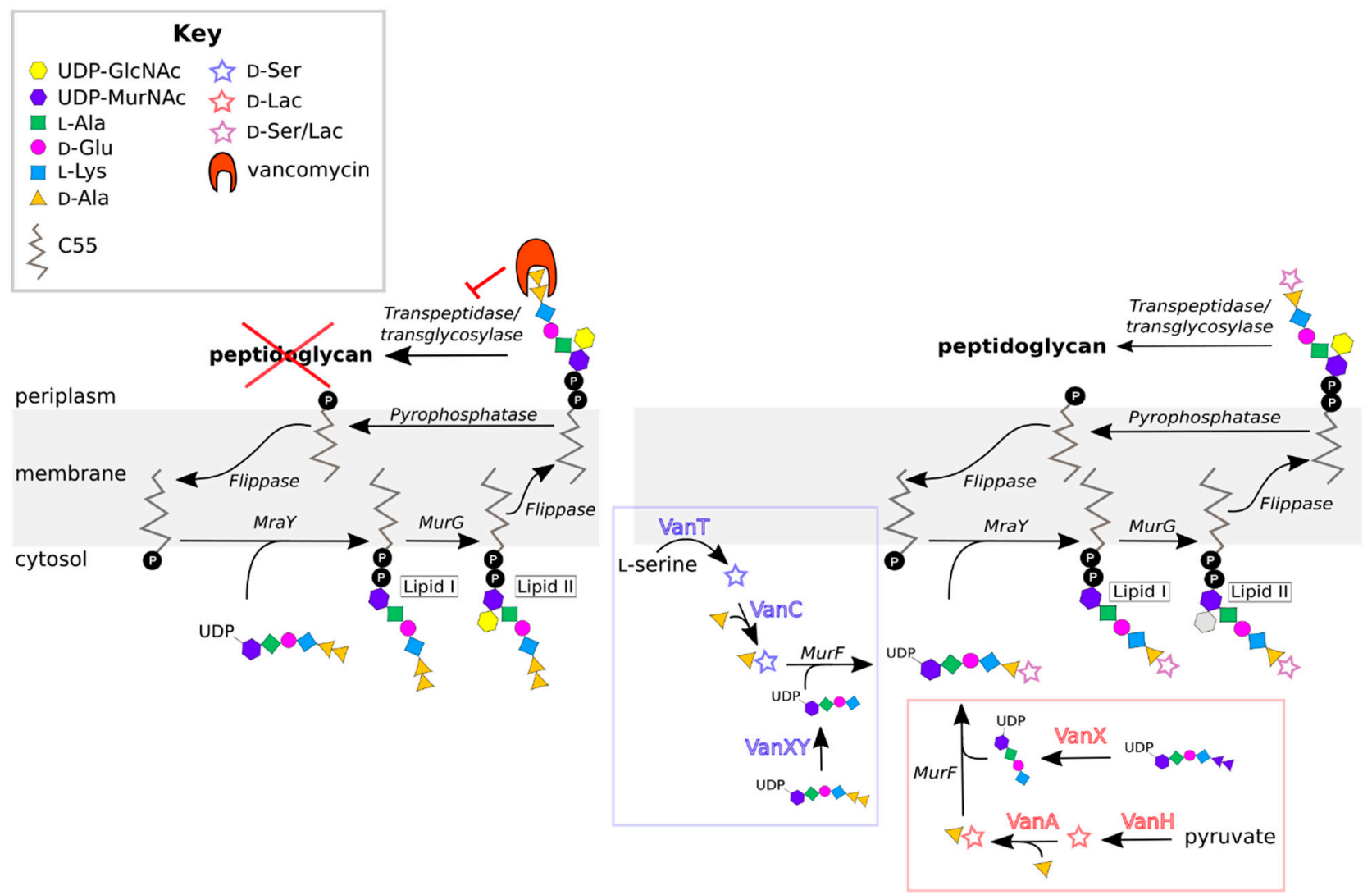

Figure 1. Vancomycin resistance mechanism. Left: In vancomycin-susceptible enterococci, vancomycin binds the D-AlaD-Ala terminus of the muramyl pentapeptide, inhibiting formation of the properly cross-linked peptidoglycan layer of the cell wall. Right: In VRE, the D-Ala-D-Ala target is remodeled to either D-Ala-D-Ser or D-Ala-D-Lac, neither of which is recognized by vancomycin.

Resistant enterococci have acquired a suite of resistance genes. Several of the associated gene products work together to alter the D-Ala-D-Ala target of vancomycin, preventing vancomycin binding (Figure 1). In different VRE strains, D-Ala-D-Ala is remodeled to either D-alanyl-D-lactate (D-Ala-D-Lac) or D-alanyl-D-serine (D-Ala-D-Ser), thereby reducing the affinity of vancomycin for its ligand [30-37]. This remodeling is accomplished by three essential enzymes encoded in the vancomycin-resistance gene cluster: First, either a pyruvate dehydrogenase (VanH) or a serine/alanine racemase (VanT); second, a ligase that joins D-lactate or D-serine to D-alanine (the naming convention for these ligases is described in Section 2.3); and third, a D-Ala-D-Ala dipeptidase (VanX or VanXY). VanH and VanT convert pyruvate to D-lactate and L-serine to D-serine, respectively [38-40], which can then be coupled with D-Ala by the appropriate ligase to form D-Ala-D-Lac or D-Ala-D-Ser $[38,39,41-53]$. This dipeptide is added to the UDP-MurNAc-tripeptide by the endogenous MurF enzyme, which has sufficiently broad specificity to accommodate the modified substrate [54]. The resulting (D-Lac/D-Ser)-UDP-MurNAc pentapeptide is incorporated into lipid II and displayed on the exterior of the cell, effectively eliminating the cell's vulnerability to vancomycin. D-Ala-D-Ala dipeptides produced by the normal 
cell-wall biosynthetic machinery are cleaved by VanX/VanXY, preventing them from being included in the nascent peptidoglycan chain [55-57]. More details about the remodeling aspects of vancomycin resistance can be found in a number of reviews [58-65].

\subsection{Vancomycin Resistance Phenotypes}

VRE isolates are assigned to one of nine types, which are genotypically and phenotypically distinct. These types are denoted by the letters A-E, G, L, M, and N, and their characteristics are summarized in Table 1. Collectively, these types are referred to as the "VRE alphabet" $[42,66]$. This alphabet should not be considered final, as new resistance types continue to be discovered [67].

Table 1. Characteristics of vancomycin resistance in the nine types of VRE.

\begin{tabular}{|c|c|c|c|c|c|c|c|c|}
\hline $\begin{array}{l}\text { VRE } \\
\text { Type }\end{array}$ & $\begin{array}{c}\text { Terminal } \\
\text { Dipeptide }\end{array}$ & Inducible & $\begin{array}{c}\text { MIC } \\
\text { Vancomycin } \\
(\mu \mathrm{g} / \mathrm{mL})\end{array}$ & $\begin{array}{c}\text { MIC } \\
\begin{array}{c}\text { Teicoplanin } \\
(\mu \mathrm{g} / \mathrm{mL})\end{array}\end{array}$ & Acquired & Transferable & Species & References \\
\hline A & D-Ala-D-Lac & Yes & 64 to $>1000$ & 16 to 512 & Yes & Yes & $\begin{array}{l}\text { E. faecalis, } \\
\text { E. faecium }\end{array}$ & {$[15,16,30,36,38,39,68-73]$} \\
\hline B & D-Ala-D-Lac & Yes & 4 to 1024 & $\leq 0.5$ & Yes & Yes & $\begin{array}{l}\text { E. faecalis, } \\
\text { E. faecium }\end{array}$ & {$[33,43,68,73-79]$} \\
\hline $\mathrm{C}$ & D-Ala-D-Ser & Yes/No & 2 to 32 & $\leq 0.5$ to 1 & No & No & $\begin{array}{l}\text { E. gallinarum, } \\
\text { E. casseliflavus / } \\
\text { flavescens }\end{array}$ & {$[32-34,46,56,80-86]$} \\
\hline $\mathrm{D}$ & D-Ala-D-Lac & No & 16 to 256 & 0.25 to 64 & Yes & No & $\begin{array}{l}\text { E. faecalis, } \\
\text { E. faecium }\end{array}$ & [45,87-92] \\
\hline $\mathrm{E}$ & D-Ala-D-Ser & Yes & 16 & 0.5 & Yes & No & E. faecalis & {$[48,49,93-95]$} \\
\hline G & D-Ala-D-Ser & Yes & 16 & 0.5 & Yes & Yes & $\begin{array}{l}\text { E. faecalis, } \\
\text { E. faecium }\end{array}$ & {$[50,51,96-98]$} \\
\hline $\mathrm{L}$ & D-Ala-D-Ser & Yes & 8 & $\mathrm{~N} / \mathrm{A}$ & Yes & No & E. faecalis & [99] \\
\hline $\mathrm{M}$ & D-Ala-D-Lac & Yes & 128 to 512 & 0.5 to $>256$ & Yes & Yes & E. faecium & {$[52,100,101]$} \\
\hline $\mathrm{N}$ & D-Ala-D-Ser & No & 12 to 16 & 0.5 & Yes & Yes & E. faecium & {$[53,102]$} \\
\hline
\end{tabular}

Most VRE isolated from human infection sites are E. faecalis or E. faecium, with the latter being the more prevalent species [80,81]. A-type E. faecium are responsible for the majority of nosocomial VRE infections and are particularly difficult to treat due to their resistance to all commonly-used glycopeptide antibiotics [103]. B- and C-type VRE are also clinically significant in humans [81,103-106]. Due to the differing levels of vancomycin resistance among these types and the various species in which they present, proper typing of isolates is critical for the treatment of VRE infections. This will become particularly important in the event that type-specific treatments are developed.

The VRE types can be categorized based on whether they use D-Ala-D-Lac or D-AlaD-Ser to achieve vancomycin resistance. VRE types $\mathrm{A}, \mathrm{B}, \mathrm{D}$, and $\mathrm{M}$ fall into the former group, and types C, E, G, L, and N into the latter. The use of D-Ala-D-Lac versus DAla-D-Ser controls the level of resistance observed. D-Ala-D-Lac is bound 1000-times less tightly by vancomycin than D-Ala-D-Ala $[26,38,74,107]$, and thus VRE in which the peptidoglycan precursors contain D-Ala-D-Lac are resistant to high concentrations of vancomycin $[45,52,87,108-110]$. D-Ala-D-Lac is also bound more weakly by teicoplanin, explaining why VRE belonging to types $\mathrm{A}, \mathrm{D}$, and $\mathrm{M}$ are also teicoplanin-resistant $[52,87,108]$.

D-Ala-D-Ser is also bound less tightly by vancomycin and teicoplanin than D-Ala-D-Ala, but the difference in affinity is less dramatic than is seen for D-Ala-D-Lac, with the remodeled precursors being bound $\sim 3$ - to 8-fold less tightly [37]. Consistent with this modestly reduced binding, VRE types using D-Ala-D-Ser (types C, E, G, L, and N) exhibit only low-to-moderate levels of resistance to vancomycin and teicoplanin [32,34,48,50,51,53,64,93,96-99,102,111,112].

Expression of vancomycin resistance genes can be inducible or constitutive. VRE exhibiting inducible expression include types A, B, C, E, G, L, and M. For these organisms, precursors containing D-Ala-D-Lac or D-Ala-D-Ser are only incorporated into the cell wall when vancomycin is present; in the absence of the antibiotic, D-Ala-D-Ala is used $[32,33,52,58,60,82,83,99,109,113]$. In contrast, VRE expressing the resistance genes constitutively (types $\mathrm{C}, \mathrm{D}$, and $\mathrm{N}$ ) produce the alternative dipeptides even in the absence of vancomycin $[32,53,58,80,82-84,111,112,114]$. The mechanisms regulating inducible and constitutive expression of resistance will be discussed in Section 3. 


\subsection{Vancomycin Resistance Genotypes}

Historically, the sequence of the D-Ala-D-Lac or D-Ala-D-Ser ligase gene has been used to classify different VRE types $[38,39,41-48,50-53,93]$. The nomenclature of these genes parallels that of their respective VRE types: The ligase gene of A-type VRE is referred to as van $A$, that of B-type vanB, and so on. VRE isolates can be typed based on van ligase sequence using a variety of PCR techniques [66,100,115-117]. Within some VRE types, the sequences of the van genes differ sufficiently to warrant subtyping. For example, C-type VRE are subdivided into C1-, C2/3-, and C4-types [44,46,47,80,85]. Other subtyped VRE include B, D, and G [97,118-123].

Several other genotypic characteristics define the VRE types, including the composition and organization of the resistance-gene cluster (Figure 2). All VRE contain the three essential HAX genes that are required for D-Ala-D-Ala remodeling, as discussed in Section 2.1 [88,124]. In addition to these genes, all operons contain the regulatory genes vanR and vanS [124], which control how the expression of vancomycin resistance is induced. Additional "accessory" genes are found in some resistance operons (A, B, $\mathrm{D}, \mathrm{G}, \mathrm{M})$, which may contribute to resistance, but are not essential. A common accessory gene is van $Y$, which encodes a D,D-carboxypeptidase that complements the action of VanX by removing the terminal D-Ala residue from UDP-MurNAc pentapeptides that have escaped remodeling [68,125-128]. Some VRE lacking the VanY protein still exhibit D,D-carboxypeptidase activity, because their VanXY proteins have dual D,D-dipeptidase and D,D-carboxypeptidase activities [57]. Other accessory genes include vanZ in A-type VRE and vanW in B- and G-type VRE $[129,130]$. These genes encode proteins of unknown function, though van $Z$ seems to play a role in teicoplanin resistance [130-132].

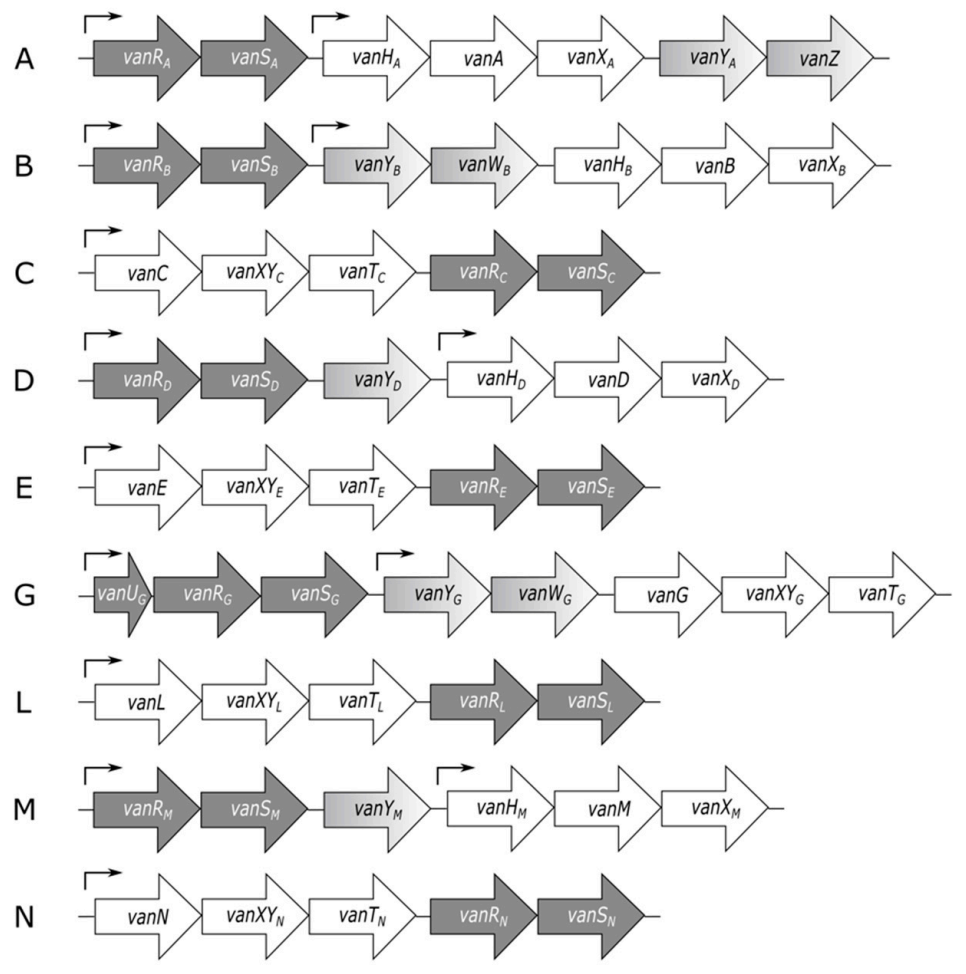

Figure 2. Organization of enterococcal vancomycin-resistance gene clusters for resistance types A-N. Regulatory genes are shown in dark gray, remodeling genes in white, and accessory genes in gray gradient. Arrows indicate the approximate positions of promoters.

In some VRE, sequences of the regions flanking the resistance operon reveal that the operon was acquired en bloc by transposition. For example, the A-type resistance operon lies within the well-characterized transposon Tn1546 [15,126,133]. Resistance can also be acquired via conjugation of plasmids harboring the resistance operon [15,43,69-72,114,134-139]. 
The majority of VRE can transfer resistance genes via conjugation, while types C, D, E, and L-type VRE cannot, suggesting that their resistance genes are chromosomally located $[43,49,52,53,75,81,87,93,94,96,99]$.

\section{Regulation of the Expression of Vancomycin Resistance}

Many types of VRE express the vancomycin-resistance phenotype only after exposure to the antibiotic, making the regulation of resistance an intriguing potential target for treatment of VRE. Specifically, compounds that inhibit the expression of resistance could function as antibiotic adjuvants [140], enhancing vancomycin's potency and restoring antibiotic sensitivity to VRE. Developing such compounds requires a detailed understanding of the regulatory mechanisms governing resistance. This review focuses on these mechanisms; it aims to complement published discussions of this topic, and to provide an update on a key question in the field: How do VRE sense vancomycin?

Regulation of the resistance phonotype in VRE depends upon the vanRS regulatory genes, which encode the VanRS two-component system. A two-component system (TCS) is a type of signaling system found in prokaryotes, archaea, and certain eukaryotes, including plants and fungi. Notably, they are not found in metazoans [141-145]. These systems sense and respond to environmental stimuli via a phosphotransfer signaling cascade [146]. TCSs consist of a sensor histidine kinase (HK) and a cognate response regulator (RR); in the VanRS TCS, these proteins are VanS and VanR, respectively. The signal sensed by the VanRS TCS is vancomycin, and the response is expression of the vancomycin-resistance genes $[147,148]$. Upon sensing vancomycin, VanS autophosphorylates on a conserved histidine residue (Figure 3). The phosphoryl group is then transferred to VanR [124,149]. When phosphorylated, VanR is activated and upregulates the transcription of the vancomycinresistance operon [149-151]. In the absence of a vancomycin signal, VanS dephosphorylates VanR, switching off the resistance pathway [148,152,153]. This general mechanism appears to be broadly applicable among different VRE types; however, regulatory details vary significantly and are discussed below, beginning with an overview of the architectures and activities of the VanRS proteins.

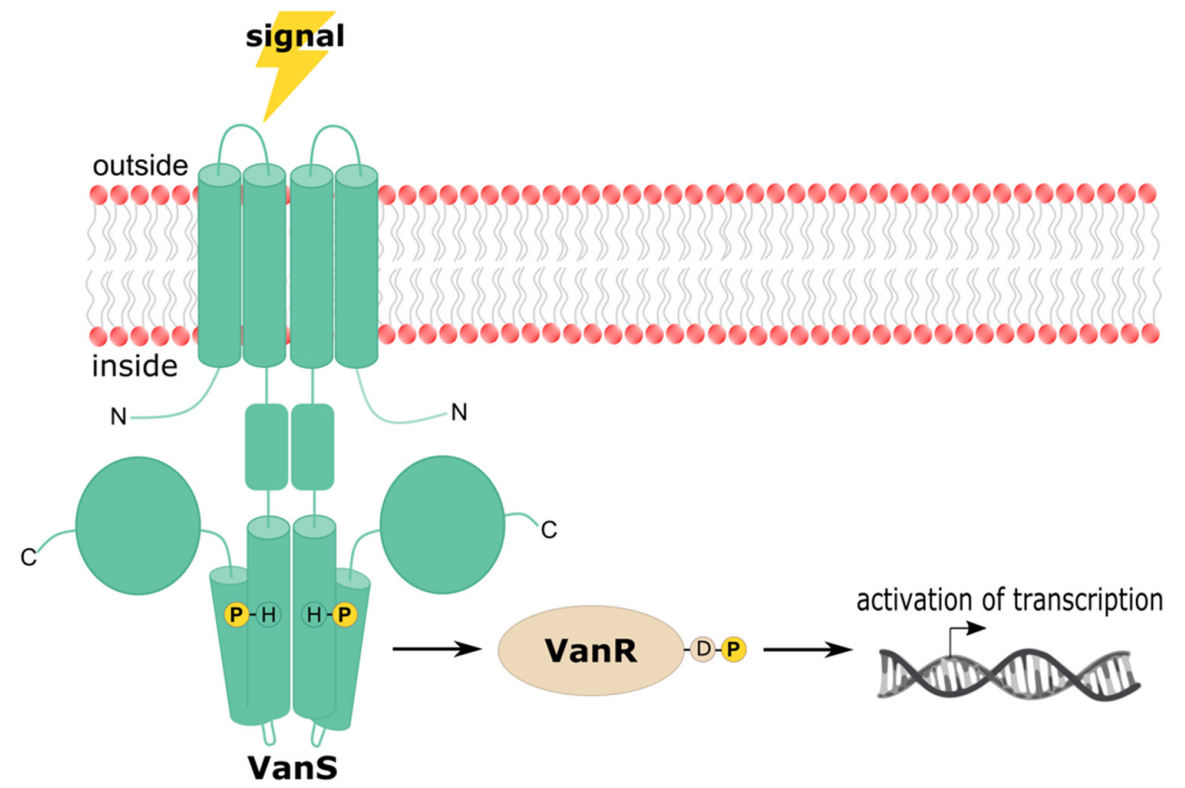

Figure 3. Signal transduction mechanism of the VanRS TCS. VanS receives a vancomycin signal that triggers autophosphorylation of VanS on a conserved histidine residue. VanS transfers the phosphoryl group to VanR, activating VanR. VanR then acts as a transcription factor and mediates expression of resistance genes. In the absence of a vancomycin signal, VanS removes the phosphoryl group from VanR, down-regulating expression of the resistance genes. 


\subsection{VanS Architecture and Activity}

VanS is a Class-I HK, belonging to the same family as EnvZ [154]. Members of this family are membrane-bound and homodimeric, and contain a periplasmic domain, a transmembrane (TM) domain consisting of two transmembrane helices, a linker region/HAMP domain, a dimerization and histidine phospho-acceptor (DHp) domain, and a catalytic ATP-binding (CA) domain. These domains participate in signal sensing, signal transduction, and/or the catalytic activity of the HK. To date, no structures have been determined for any VRE VanS proteins, and the topologies described herein are therefore inferred from known structures of related HKs and protein prediction software $[155,156]$. The predicted domains of VanS are listed for each VRE ortholog in Table 2.

Table 2. SMART-predicted domains of the VRE VanS proteins [155].

\begin{tabular}{|c|c|c|c|c|c|c|c|c|c|}
\hline \multirow[b]{2}{*}{$\begin{array}{l}\text { VanS } \\
\text { Ortholog }\end{array}$} & \multirow[b]{2}{*}{$\begin{array}{l}\text { Protein Sequence } \\
\text { Accession }^{\mathbf{a}}\end{array}$} & \multicolumn{8}{|c|}{ Location and Length } \\
\hline & & $\mathrm{TMH}^{\mathrm{b}}$ & TMH2 & $\begin{array}{c}\text { Periplasmic } \\
\text { Domain }\end{array}$ & $\begin{array}{l}\text { Linker } \\
\text { Region }\end{array}$ & $\begin{array}{l}\text { HAMP } \\
\text { Domain }\end{array}$ & $\underset{\text { Domain }}{\text { DHp }}$ & $\begin{array}{c}\text { Histidine } \\
\text { Phospho-Acceptor } \\
\text { (Residue Number) }\end{array}$ & $\begin{array}{c}\text { CA } \\
\text { Domain }\end{array}$ \\
\hline $\mathrm{A}$ & $\begin{array}{c}\text { WP_002305818.1 } \\
{[41]}\end{array}$ & $\begin{array}{l}19-41 \\
(23 \text { aа) }\end{array}$ & $\begin{array}{l}78-97 \\
(20 \text { aa) }\end{array}$ & $\begin{array}{l}42-77 \\
(26 \text { aa) }\end{array}$ & $\begin{array}{l}98-153 \\
(56 \text { aa })\end{array}$ & & $\begin{array}{c}154-221 \\
(68 \text { aa })\end{array}$ & 164 & $\begin{array}{l}266-376 \\
(111 \mathrm{aa})\end{array}$ \\
\hline B & $\begin{array}{c}\text { WP_002368696.1 } \\
{[42]}\end{array}$ & $\begin{array}{c}7-29 \\
(23 \mathrm{aa})\end{array}$ & $\begin{array}{c}133-155 \\
(23 \mathrm{aa})\end{array}$ & $\begin{array}{l}30-132 \\
(103 \text { aa })\end{array}$ & $\begin{array}{c}156-222 \\
(67 \mathrm{aa})\end{array}$ & $\begin{array}{l}157-208 \\
(52 \mathrm{aa})\end{array}$ & $\begin{array}{c}223-289 \\
(67 \mathrm{aa})\end{array}$ & 233 & $\begin{array}{l}334-445 \\
(112 \text { aa })\end{array}$ \\
\hline $\mathrm{C} 1$ & WP_063856733.1 & $\begin{array}{c}1-17 \\
(17 \mathrm{aa})\end{array}$ & $\begin{array}{l}37-56 \\
(20 \mathrm{aa})\end{array}$ & $\begin{array}{l}18-36 \\
(23 \mathrm{aa})\end{array}$ & $\begin{array}{l}57-114 \\
(58 \mathrm{aa})\end{array}$ & & $\begin{array}{c}115-182 \\
(68 \text { aа })\end{array}$ & 125 & $\begin{array}{l}227-337 \\
(111 \mathrm{aa})\end{array}$ \\
\hline $\mathrm{C} 2 / 3$ & $\begin{array}{c}\text { WP_016608740.1 } \\
{[47]}\end{array}$ & $\begin{array}{c}4-23 \\
(20 \mathrm{aa})\end{array}$ & $\begin{array}{l}36-58 \\
(23 \mathrm{aa})\end{array}$ & $\begin{array}{l}24-35 \\
(12 \mathrm{aa})\end{array}$ & $\begin{array}{l}59-114 \\
(56 \mathrm{aa})\end{array}$ & & $\begin{array}{c}115-182 \\
(68 \mathrm{aa})\end{array}$ & 125 & $\begin{array}{l}227-337 \\
(111 \text { aa })\end{array}$ \\
\hline $\mathrm{C} 4$ & ABX79412.1 (222) & $\begin{array}{c}4-23 \\
(20 \mathrm{aa})\end{array}$ & $\begin{array}{l}36-58 \\
(23 \mathrm{aa})\end{array}$ & $\begin{array}{l}24-35 \\
(12 \text { aa) }\end{array}$ & $\begin{array}{l}59-114 \\
(56 \text { aa })\end{array}$ & & $\begin{array}{c}115-182 \\
(68 \text { aа })\end{array}$ & 125 & $\begin{array}{l}227-337 \\
(111 \text { aa })\end{array}$ \\
\hline $\mathrm{D}$ & $\begin{array}{l}\text { WP_063856730.1 } \\
{[45]}\end{array}$ & $\begin{array}{l}21-43 \\
(23 \mathrm{aa})\end{array}$ & $\begin{array}{l}76-98 \\
(23 \mathrm{aa})\end{array}$ & $\begin{array}{c}44-75 \\
(32 \mathrm{aa})\end{array}$ & $\begin{array}{l}99-155 \\
(57 \mathrm{aa})\end{array}$ & & $\begin{array}{c}156-223 \\
(68 \mathrm{aa})\end{array}$ & 166 & $\begin{array}{l}268-379 \\
(112 \mathrm{aa})\end{array}$ \\
\hline $\mathrm{E}$ & $\begin{array}{c}\text { WP_063856734.1 } \\
{[49]}\end{array}$ & $\begin{array}{l}13-35 \\
(23 \mathrm{aa})\end{array}$ & $\begin{array}{l}55-77 \\
(23 \mathrm{aa})\end{array}$ & $\begin{array}{c}36-54 \\
(19 \text { aа })\end{array}$ & $\begin{array}{l}78-134 \\
(57 \mathrm{aa})\end{array}$ & & $\begin{array}{c}135-205 \\
(71 \mathrm{aa})\end{array}$ & 145 & $\begin{array}{l}250-357 \\
(108 \mathrm{aa})\end{array}$ \\
\hline G & $\begin{array}{c}\text { WP_063856732.1 } \\
{[50]}\end{array}$ & $\begin{array}{l}12-34 \\
(23 \mathrm{aa})\end{array}$ & $\begin{array}{l}70-90 \\
(21 \mathrm{aa})\end{array}$ & $\begin{array}{l}35-69 \\
(35 \mathrm{aa})\end{array}$ & $\begin{array}{l}91-144 \\
(54 \mathrm{aa})\end{array}$ & & $\begin{array}{c}145-212 \\
(68 \text { aa })\end{array}$ & 155 & $\begin{array}{l}257-366 \\
(110 \mathrm{aa})\end{array}$ \\
\hline $\mathrm{L}$ & $\begin{array}{c}\text { WP_063856745.1 } \\
\text { [99] }\end{array}$ & $\begin{array}{l}17-39 \\
(23 \mathrm{aa})\end{array}$ & $\begin{array}{c}66-88 \\
(23 \mathrm{aa})\end{array}$ & $\begin{array}{l}40-65 \\
(26 \text { aa })\end{array}$ & $\begin{array}{l}89-140 \\
(52 \text { aa) }\end{array}$ & & $\begin{array}{c}141-208 \\
(68 \mathrm{aa})\end{array}$ & 151 & $\begin{array}{l}253-364 \\
(112 \mathrm{aa})\end{array}$ \\
\hline M & $\begin{array}{c}\text { WP_063856748.1 } \\
{[52]}\end{array}$ & $\begin{array}{l}12-31 \\
(20 \mathrm{aa})\end{array}$ & $\begin{array}{l}57-79 \\
(23 \mathrm{aa})\end{array}$ & $\begin{array}{l}32-56 \\
(35 \mathrm{aa})\end{array}$ & $\begin{array}{l}80-140 \\
(61 \text { aa })\end{array}$ & $\begin{array}{l}81-133 \\
(53 \mathrm{aa})\end{array}$ & $\begin{array}{c}141-208 \\
(68 \mathrm{aa})\end{array}$ & 151 & $\begin{array}{l}253-364 \\
(112 \text { aa })\end{array}$ \\
\hline $\mathrm{N}$ & $\begin{array}{c}\text { WP_063856749.1 } \\
{[53]}\end{array}$ & $\begin{array}{l}15-37 \\
(23 \mathrm{aa})\end{array}$ & $\begin{array}{c}61-83 \\
(23 \mathrm{aa})\end{array}$ & $\begin{array}{l}38-60 \\
(23 \mathrm{aa})\end{array}$ & $\begin{array}{l}84-140 \\
(57 \mathrm{aa})\end{array}$ & & $\begin{array}{c}141-208 \\
(68 \mathrm{aa})\end{array}$ & 151 & $\begin{array}{l}253-364 \\
(112 \text { aa) }\end{array}$ \\
\hline
\end{tabular}

${ }^{a}$ Representative VanS protein sequences were chosen because they belong to the first resistance gene cluster of each type to be characterized. For E-type, the accession listed is that of VanS $S_{\mathrm{E}}$ from strain N00-410. There is no VanS $\mathrm{E}$ protein sequence available from strain BM4405, the first E-type strain to have its resistance gene cluster characterized. ${ }^{b}$ Numbers in each entry correspond to the range of residue numbers forming the relevant domain.

\subsubsection{Periplasmic Domain}

In the EnvZ family of HKs, the periplasmic domain is thought to detect the activating signal, although in some cases signals may be sensed by other domains (e.g., the TM domain). The VanS periplasmic domain (together with the TM domain and HAMP domain/linker region) lies within the N-terminal half of the protein, which displays considerably more sequence variability than the C-terminal half. The size of the VanS periplasmic domain also differs greatly between the different VRE types, ranging from 12 to 103 residues in length. This heterogeneity in length and composition suggests that periplasmic domains from different VanS orthologs may adopt different structures and thus sense vancomycin differently. Based on the length of the periplasmic domain (Table 2), VanS proteins can be described as either "intramembrane-sensing" or "periplasmic-sensing" HKs. HKs with short periplasmic domains ( $<50$ amino acids) are said to be "intramembrane-sensing," meaning they detect signals via the TM domain rather than by the periplasmic domain directly [146], and likely sense changes in membrane properties resulting from the signal. All VanS orthologs except $\operatorname{VanS}_{\mathrm{B}}$ fall into this group. VanS $\mathrm{B}_{\mathrm{B}}$ is categorized as "periplasmicsensing" HK, because its periplasmic domain contains 103 amino acids. Consistent with this classification, the $\mathrm{VanS}_{\mathrm{B}}$ periplasmic domain is predicted to adopt a PAS-like structure [157] (P. Rotsides, unpublished results), similar to the ligand-binding periplasmic PAS domains found in multiple other HKs [158-164]. We caution, however, while sensing mechanisms of different HKs are commonly inferred from the length of the periplasmic 
domain, this approach alone is not definitive. Possible signal-sensing mechanisms of different VanS orthologs will be discussed in more detail in Section 3.3.

\subsubsection{TM Domain}

TM domains contribute to signal sensing in some HKs (including possibly VanS). In addition, the TM domain transduces the signal to the catalytic domain, thereby bridging the sensing and catalytic events in the HK [165]. Beginning at the N-terminus, the first transmembrane $\alpha$-helix (TMH1) passes the membrane from inside to outside the cell; here, it is linked via the periplasmic domain to the second transmembrane $\alpha$-helix (TMH2), which crosses the membrane again to reenter the cell.

Molecular structures are key contributors to our knowledge of sensing and signal transduction. However, obtaining structural information for membrane-bound domains like the TM domain is challenging. Nonetheless, a general idea of how signal transduction can function through the TM domain has been developed. This model, based on HK models derived from crystallographic, NMR, and disulfide cross-linking experiments, suggests that signals are transduced by some combination of rotations, translations, and scissoring motions of the TM helices [166-169]. However, this conceptual framework allows for many possible variations, and in the case of VanS, it is unknown precisely how the TM domain changes conformation in the presence of vancomycin. Indeed, even though different VanRS TCSs share a common signal (vancomycin) and response (resistance gene expression), it cannot be concluded that all VanS proteins share a common signaltransduction mechanism, as underlined by the low sequence identity of the $\mathrm{N}$-terminal regions of VanS orthologs.

\subsubsection{Linker Region/HAMP Domain}

All VanS proteins contain a membrane-proximal region connecting TMH2 and the DHp domain, which is responsible for propagating the signal to the DHp and CA domains; deletion of this region abrogates HK activity $[170,171]$. This linker region contains $\sim 60$ amino acids (Table 2). In most VanS proteins, this region is not annotated as containing any specific domain, but in $\operatorname{VanS}_{B}$ and $\operatorname{VanS}_{M}$ this region is predicted to adopt a HAMPdomain fold $[155,172]$. HAMP domains are so-named by virtue of their presence in HKs, adenylyl cyclases, methyl-carrier proteins, and phosphatases [172,173]. HAMP-domain sequences are not highly conserved, but they share a canonical two-helix coiled-coil structure [168]; in dimeric HKs, the coiled coils from each protomer associate into a parallel four-helix bundle [174-176]. While the linker regions of the other VRE VanS orthologs have not yet been annotated as HAMP domains, they are predicted to be $\alpha$-helical; thus, given the lack of sequence conservation within HAMP domains, it is entirely possible one or more of these VanS proteins will also prove to contain a HAMP domain.

\subsubsection{DHp Domain}

Following the linker region/HAMP domain is the conserved kinase region of the HK, consisting of the DHp and CA domains. These domains are 70 and $\sim 110$ amino acids in length, respectively. The DHp domain earns the first half of its name by contributing to the dimerization of HK protomers; for example, in the EnvZ family of HKs, the DHp domain forms a long helical hairpin, with the two $\alpha$-helices of each protomer dimerizing to form a four-helix bundle $[177,178]$. Rearrangements of this helical bundle permit switching between kinase and phosphatase activities. The first third of the first DHp helix harbors the conserved histidine (His164 in A-type VanS), which is autophosphorylated upon HK activation $[179,180]$. Situated within the aptly-named H box, this histidine residue is absolutely required for signal transduction [165]. The H-box represents the site at which the CA domain docks, bringing the CA domain into close proximity to the histidine phospho-acceptor [165]. In addition to its importance to the autophosphorylation activity of the HK, the $\mathrm{H}$ box is required for phosphotransfer and phosphatase activities [181]. Phosphotransfer from the H-box to the RR is made possible by the binding of the RR to the 
lower portion of the DHp four-helix bundle [141,182]; this portion of the DHp also contains the $\mathrm{X}$ region, which is important for phosphatase activity [181].

For the A-type VanRS proteins, the aforementioned binding interaction has recently been quantified. Both full-length, detergent-solubilized $\mathrm{VanS}_{\mathrm{A}}$ and the cytosolic portion of VanS $\mathrm{A}_{\mathrm{A}}$ display low micromolar affinity for $\operatorname{VanR}_{\mathrm{A}}$, with $K_{\mathrm{D}}$ values of $1.9 \pm 0.7 \mu \mathrm{M}$ and $6.8 \pm 1.4 \mu \mathrm{M}$, respectively [183]. Perhaps unsurprisingly, these values fall within the low-micromolar affinity window identified for other HK-RR interactions [184].

\subsubsection{CA Domain}

In prokaryotic HKs, the CA domain adopts an $\alpha / \beta$ sandwich topology known as the Bergerat fold $[185,186]$. Within this domain, the ATP required for autophosphorylation is bound in a crevice within two $\alpha$-helices, partially covered by a mobile loop called the "ATP lid." The ATP-binding site and the ATP lid encompass several conserved motifs known as the N, G1, F, and G2 boxes $[154,179,180]$. Mutations in these conserved motifs can have different effects on HK activity; in particular, some abrogate phosphatase activity, which can cause constitutive expression of the resistance genes. Several such mutations are discussed in Section 3.4.

\subsection{VanR Architecture and Activity}

VanR belongs to the OmpR family of RRs $[187,188]$ and is divided into two domains: an N-terminal receiver domain and a C-terminal effector domain, joined by a flexible linker [189]. These domains work together to convert the vancomycin signal sensed by VanS into a transcriptional response. There are no published structures of VanR proteins from VRE, but structures are known for many other OmpR-family RRs, including VanR from S. coelicolor [190]. These orthologous structures allow us to make structural inferences for the VRE VanR proteins.

\subsubsection{Receiver Domain}

The receiver domain accepts the phosphoryl group from VanS, with phosphorylation occurring on a conserved aspartate residue (Asp53 for $\operatorname{VanR}_{\mathrm{A}}$ ). In OmpR-related RRs, this aspartate is situated at the end of the third $\beta$-strand of an $\alpha / \beta$ sandwich [189]. Once phosphorylated, the receiver domain undergoes a conformational change, allowing it to dimerize at a conserved $\alpha 4-\beta 5-\alpha 5$ interface [191].

\subsubsection{Effector Domain}

The effector domain of VanR is a winged-helix DNA-binding domain [187,192], with helix $\alpha 8$ serving as the recognition helix of the winged-helix motif. Insertion of this helix into the major groove of the DNA allows VanR to bind to its target promoters, thereby facilitating expression of the resistance genes, as well as upregulation of the vanRS genes. VanR targets either one or two promoters, depending on the relative orientations of the vanRS and vanHAX genes. For resistance operons in which the vanRS genes are located upstream of the remodeling-enzyme genes (types A, B, D, G, and M; see Figure 2), VanR recognizes two distinct promoters, one controlling expression of vanHAX and the other controlling expression of vanRS $[150,151,193,194]$. However, for operons in which the vanRS genes lie downstream of the remodeling genes (types $\mathrm{C}, \mathrm{E}, \mathrm{L}$, and N), only a single promoter is used $[53,83,94,193]$. $\operatorname{VanR}_{\mathrm{A}}$ and $\operatorname{VanR}_{\mathrm{B}}$ have been shown to bind their DNA targets in both the phosphorylated and unphosphorylated states; however, transcription of resistance genes is achieved only when VanR is phosphorylated [129,148-150,152,153]. A plausible model to explain this observation is that phosphorylation-induced dimerization enhances DNA binding, either by conformational changes that give rise to optimal orientation of the effector domains and/or through an avidity effect $[150,151,195,196]$. This process is then reversed by dephosphorylation [197-201].

The activities of the VRE VanR proteins will be more clearly understood once structures are determined for these proteins. Although it is possible to formulate models of VanR 
architecture by examining structures of related RRs, the specific details revealed by true experimental structures may provide insights into treating VRE. For example, therapeutics that disrupt the VanR-VanS or VanR-DNA interactions might restore vancomycin sensitivity to VRE, and are thus worth investigating.

\subsection{VanS Sensing of Vancomycin}

The expression of vancomycin resistance is initiated when VanS detects vancomycin in the periplasmic space. The mechanism by which this occurs remains one of the principal open questions in the field. Addressing this question has proven challenging, at least in part because VanS is an integral membrane protein, and therefore a difficult subject for biochemical and biophysical analysis. Furthermore, different VanS orthologs may employ different vancomycin-detection mechanisms, meaning that insights gleaned from one system cannot necessarily be translated to another.

Broadly speaking, VanS could detect vancomycin via two distinct mechanisms: It might detect the antibiotic directly, by binding to it (Figure 4A), or indirectly, by sensing some downstream effect of vancomycin activity (Figure 4B). There is currently little consensus as to which model is correct for any given VRE type.

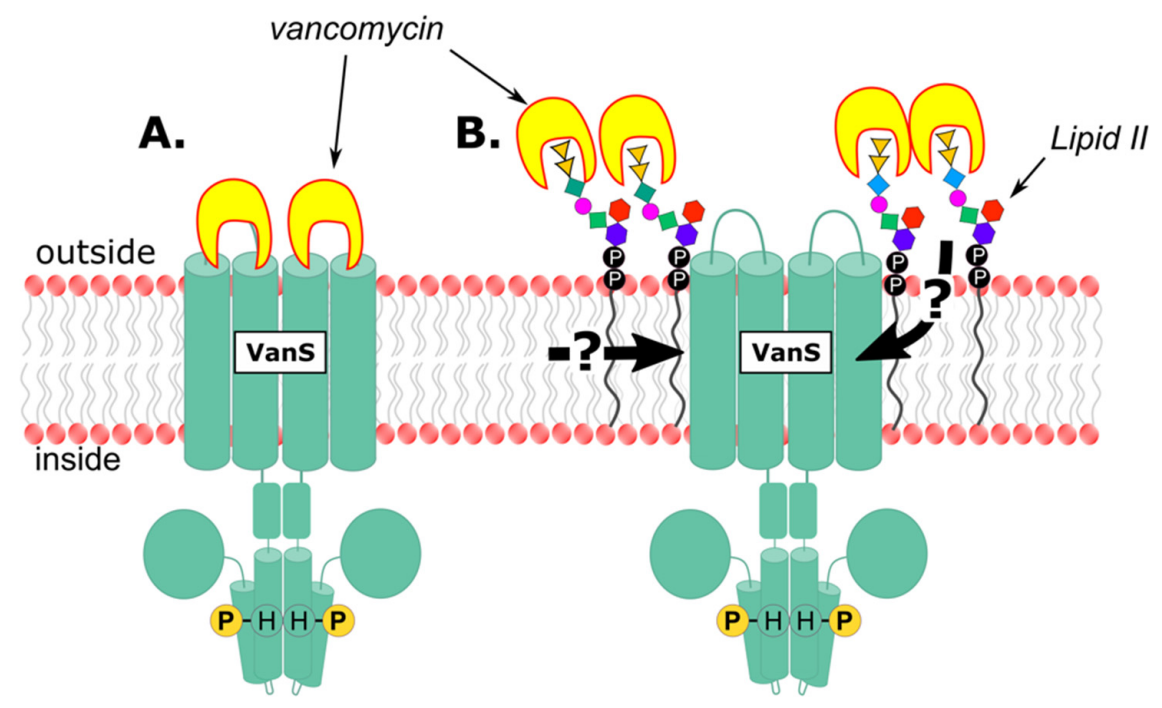

Figure 4. Hypothetical models illustrating vancomycin sensing hypotheses. (A) Direct sensing by binding of vancomycin to the periplasmic domain of VanS. (B) Indirect sensing of vancomycin by detection of some not-yet-determined, downstream effect resulting from the vancomycin-D-Ala-DAla binding event. Two hypothetical sensing routes (detecting membrane stress or Lipid II buildup) are indicated by the heavy black arrows.

Direct binding provides the most conceptually straightforward model. A directbinding mechanism has been most convincingly demonstrated for the non-VRE species Streptomyces coelicolor, which expresses the VanS ortholog VanS $\mathrm{S}_{\mathrm{Sc}}$. A direct interaction between vancomycin-VanS $S_{\mathrm{Sc}}$ was deduced using a vancomycin photoaffinity probe, which was shown to label native protein in S. coelicolor membranes, as well as recombinant VanS $_{\mathrm{Sc}_{\mathrm{c}}}$ in E. coli membranes [202]. Unlabeled vancomycin effectively competed with the vancomycin photoprobe, arguing for the specificity of this interaction. While this result is compelling, it must be noted that these studies employed membrane preparations that contained lipid II; vancomycin binding to lipid II would tend to produce a high local concentration of the antibiotic, which could give rise to labeling from nonspecific proximity. However, this concern is lessened by a recent NMR study that shows a direct interaction between vancomycin and a peptide corresponding to the periplasmic domain of $\operatorname{VanS}_{\mathrm{Sc}}$ [203].

In contrast to the direct-binding model, indirect-detection models include any mechanisms that do not involve a direct physical interaction between vancomycin and VanS. 
One such indirect model suggests that VanS senses increased lipid II levels resulting from vancomycin's inhibition of transglycosylase and transpeptidase enzymes (illustrated in Figure 4B) [204]. An alternative model posits that VanS senses changes in membrane properties resulting from vancomycin activity. A precedent for the latter model may be found in other HKs that are thought to alter conformation within the membrane in response to changes in temperature, thereby functioning as "molecular thermometers," such as DesK in Bacillus subtilis or CorS in Pseudomonas syringae [205,206].

Yet another potential indirect-detection mechanism involves the regulation of VanS by one or more additional proteins. Many HKs are known to be regulated by other proteins, which may be upregulated in the presence of the HK stimulus, or may themselves bind the stimulus $[207,208]$. For example, the stress-sensing HK LiaS of B. subtilis is regulated by the small membrane protein LiaF. LiaF inhibits LiaS, turning "off" expression of the LiaSregulated genes in the absence of signal [209]. LiaS adopts the same domain architecture as most VanS orthologs, having two transmembrane helices and a small periplasmic domain [210]. Hence, the LiaS example suggests that regulation by auxiliary proteins is at least formally possible for VanS proteins; however, to our knowledge this mechanism has not been carefully investigated for any VanS orthologs.

\subsubsection{VanS $_{\mathrm{A}}$ Sensing of Vancomycin}

VanS $_{A}$ is the most well-studied of the VRE VanS orthologs, and much evidence is available that relates to its mechanism of vancomycin sensing. Early work focused on determining which compounds activate $\mathrm{VanS}_{\mathrm{A}}$, with activation being assessed by the ratio of D-Ala-D-Lac- to D-Ala-D-Ala- in peptidoglycan precursors, the activity of the D,D-dipeptidase VanX, or the expression levels of the vanHAX genes $[29,211-214]$. These experiments revealed that $V_{a n} S_{A}$ is activated by a myriad of antimicrobial agents that interfere with cell-wall synthesis and/or compromise the integrity of the cell envelope. These compounds include glycopeptide antibiotics such as teicoplanin, avoparcin, ristocetin, and of course vancomycin, as well as structurally unrelated compounds such as bacitracin, amphomycin, moenomycin, penicillin $\mathrm{G}$, and tunicamycin. The structural heterogeneity of these different activators would seem to argue against a direct-binding model, since it is unlikely that a single binding site could recognize such a diverse array of ligands. Because most of the activating compounds listed interfere with cell-wall biosynthesis, a model in which $V_{a n S}$ A senses vancomycin by detecting lipid II accumulation appears viable $[29,212]$; however, such indirect sensing mechanisms have not been thoroughly investigated for $\operatorname{VanS}_{\mathrm{A}}$. We note that not all activating compounds need act by the same mechanism. For example, glycopeptide antibiotics appear to be more potent activators of $\mathrm{VanS}_{\mathrm{A}}$ than other agents [212-214]; hence, it is possible that $\mathrm{VanS}_{\mathrm{A}}$ directly binds vancomycin and other glycopeptides, whereas other compounds activate the enzyme through different means.

Late-stage intermediates in cell-wall biosynthesis, such as lipid II, are not the only potential candidates for activating $\operatorname{VanS}_{\mathrm{A}}$. This was shown by Ulijasz et al., who devised a $V_{\text {VanS }}$ A reporter system in B. subtilis, using the PvanH promoter fused to a lacZ gene [147]. They found that fosfomycin and D-cycloserine (albeit at high concentrations) could activate their reporter, as well as cell-wall hydrolytic enzymes such as lysozyme and mutanolysin. These treatments cause the build-up of a wide range of different peptidoglycan precursors and breakdown products. The structural heterogeneity of these molecules again makes it unlikely that a single binding site in VanS ${ }_{\mathrm{A}}$ directly recognizes them. However, membrane stress is a common consequence of all of these treatments, and may therefore be a more credible candidate for the activating signal. Consistent with this idea, the membraneperturbing agent chlorhexidine gluconate also activates $V_{a n S} S_{A}$, as revealed by RNA-seq analysis in E. faecium [215]. Control experiments in a $\Delta v a n R S$ strain showed no increase in vanHAX transcript abundance, implicating VanS in sensing the chlorhexidine [215].

In addition to the cellular assays for $\mathrm{VanS}_{\mathrm{A}}$ activation described above, activation can also be probed in the purified enzyme, by measuring its autophosphorylation, phosphotransfer, and dephosphorylation activities. If vancomycin directly activates $\mathrm{VanS}_{\mathrm{A}}$, it 
should increase autophosphorylation and phosphotransfer activity, decrease phosphatase activity, or both. However, detergent-solubilized VanS $_{\mathrm{A}}$ displays no change in any of its activities in the presence of vancomycin [183]. Adverse effects of detergent micelles on VanS $_{\mathrm{A}}$ activity can be ruled out, since when VanS $\mathrm{A}_{\mathrm{A}}$ is reconstituted in either amphipols or nanodiscs, its autophosphorylation and dephosphorylation activities also do not change in the presence of vancomycin $[183,201]$. These in vitro findings argue against a direct-binding model for $\operatorname{VanS}_{\mathrm{A}}$.

Despite this large body of evidence favoring an indirect-detection model for $\mathrm{VanS}_{\mathrm{A}}$, evidence also exists supporting a direct-binding model [216-221]. A sedimentation-velocity experiment performed using detergent-solubilized $\operatorname{VanS}_{\mathrm{A}}$ revealed a shift in the sedimentation coefficient of $\operatorname{VanS}_{\mathrm{A}}$ in the presence of vancomycin, suggesting that vancomycin induces a conformational change in the protein, presumably via a direct interaction [222,223]. Additionally, vancomycin was found to alter the circular dichroism spectrum of detergentsolubilized $\operatorname{VanS}_{\mathrm{A}}$, which has been interpreted as evidence for direct binding of the antibiotic, with a dissociation constant $K_{\mathrm{D}}$ of approximately $70 \mu \mathrm{M}$ [222,224]. Interestingly, this relatively high $K_{\mathrm{D}}$ value is roughly one to two orders of magnitude higher than the antibiotic concentrations required to inhibit growth of antibiotic-sensitive Enterococci [216-221], raising questions about whether this binding is relevant to activation of the resistance phenotype. An additional caveat is that these results were obtained in the presence of detergents, which can alter the conformations and activities of many membrane proteins. In particular, VanS ${ }_{A}$ 's autophosphorylation activity is highly sensitive to detergents $[183,225]$.

Finally, as we weigh indirect vs. direct sensing mechanisms for $\operatorname{VanS}_{\mathrm{A}}$, we note that models can be conceived that combine elements of both mechanisms. For example, VanS $_{\mathrm{A}}$ activation might entail recognizing a vancomycin-lipid II complex, rather than the antibiotic alone. Support for this idea comes from the S. coelicolor system, where VanS activation only occurs when vancomycin binds its D-Ala-Ala target [226], even though vancomycin has been shown to bind directly to the sensor's periplasmic domain [203].

In summary, while the preponderance of evidence currently points toward an indirectdetection mechanism for $\mathrm{VanS}_{\mathrm{A}}$, tantalizing data also exist that support a direct-binding model. Ultimately, this question will not be resolved without further study.

\subsubsection{VanS $_{B}$ Sensing of Vancomycin}

The vancomycin-sensing mechanism of $\operatorname{VanS}_{\mathrm{B}}$ is less well-studied than that of $\operatorname{VanS}_{\mathrm{A}}$, but the cumulative weight of the evidence points to a direct-sensing mechanism. First, VanS $_{B}$ is activated only by vancomycin [212], in stark contrast with VanS $S_{A}$. In the preceding section, we noted that it is difficult to conceive of how $\operatorname{VanS}_{A}{ }^{\prime}$ s small periplasmic domain would be able to recognize the structurally diverse set of molecules that activate resistance, providing suggestive support for an indirect-binding mechanism for VanS $\mathrm{A}_{\mathrm{A}}$. Conversely, $\mathrm{VanS}_{\mathrm{B}}$ 's narrow specificity for its activator makes it plausible that the protein does bind vancomycin directly.

VanS $_{\mathrm{B}}$ 's ligand preference maps to its periplasmic domain, with mutations in this region altering ligand specificity and rendering B-type E. faecalis resistant to teicoplanin $[227,228]$. These mutations will be discussed in more detail in Section 3.4. The VanS $S_{B}$ periplasmic domain does not exhibit a high degree of sequence homology to any domains of known structure; however, threading experiments predict that it can adopt a PAS-domain fold (P. Rotsides, unpublished results). This would be consistent with the lack of homology with other proteins, since PAS domains typically exhibit low pairwise similarities with one another, and contain no highly conserved residues [157]. A PAS domain in VanS $S_{B}$ would not be unprecedented among $\mathrm{HKs}$, as a number of other sensor kinases possess periplasmic PAS domains, including CitA, PhoQ, and DcuS $[163,164,229]$. However, VanS ${ }_{B}$ is the only enterococcal VanS ortholog for which a periplasmic ligand-binding domain is predicted. Combined with the specificity of $\mathrm{VanS}_{\mathrm{B}}$ for vancomycin, this observation suggests that $\mathrm{VanS}_{\mathrm{B}}$ may sense vancomycin by direct binding, which could make it an outlier among the VRE VanS proteins. 


\subsection{Inducibility of Vancomycin Resistance Expression}

In the canonical model for VanRS function, exposure to vancomycin leads to expression of the vancomycin-resistance genes, via the intermediate steps of activation and autophosphorylation of VanS and subsequent phosphotransfer to VanR. However, in practice, vancomycin induces expression of resistance in only a subset of VRE types: A, B, E, $\mathrm{G}, \mathrm{L}, \mathrm{M}$, and some C. In contrast, in other VRE types (D, N, and some C) vancomycinresistance genes are expressed constitutively, regardless of whether the antibiotic is present. By comparing and contrasting the inducible and constitutive systems, we can gain insights into mechanisms of VanRS signaling.

As noted earlier, VanS possesses both kinase activity (i.e., autophosphorylation and phosphotransfer to VanR) and phosphatase activity (dephosphorylation of VanR). In inducible systems, vancomycin induces expression of resistance by tipping the kinase/phosphatase balance in favor of the former [148]. However, in the non-inducible VRE types (C, D, and N), VanR is constitutively phosphorylated. This might result from VanS proteins having constitutively active kinase or defective phosphatase activities, or from the complete loss of VanS (note that in the absence of VanS, VanR can still be phosphorylated by small-molecule phosphoryl donors such as acetyl phosphate). Since phosphorylated VanR has a long half-life (up to $17.6 \mathrm{~h}$ ), resistance genes can be transcribed for a considerable amount of time following a phosphorylation event [149].

Much of our knowledge about the inducibility of vancomycin resistance is derived from analysis of mutant VanS proteins with constitutive kinase activities/loss of phosphatase activity $[64,193]$. A handful of these mutants are shown in Figure 5 and will be discussed in the following sections.

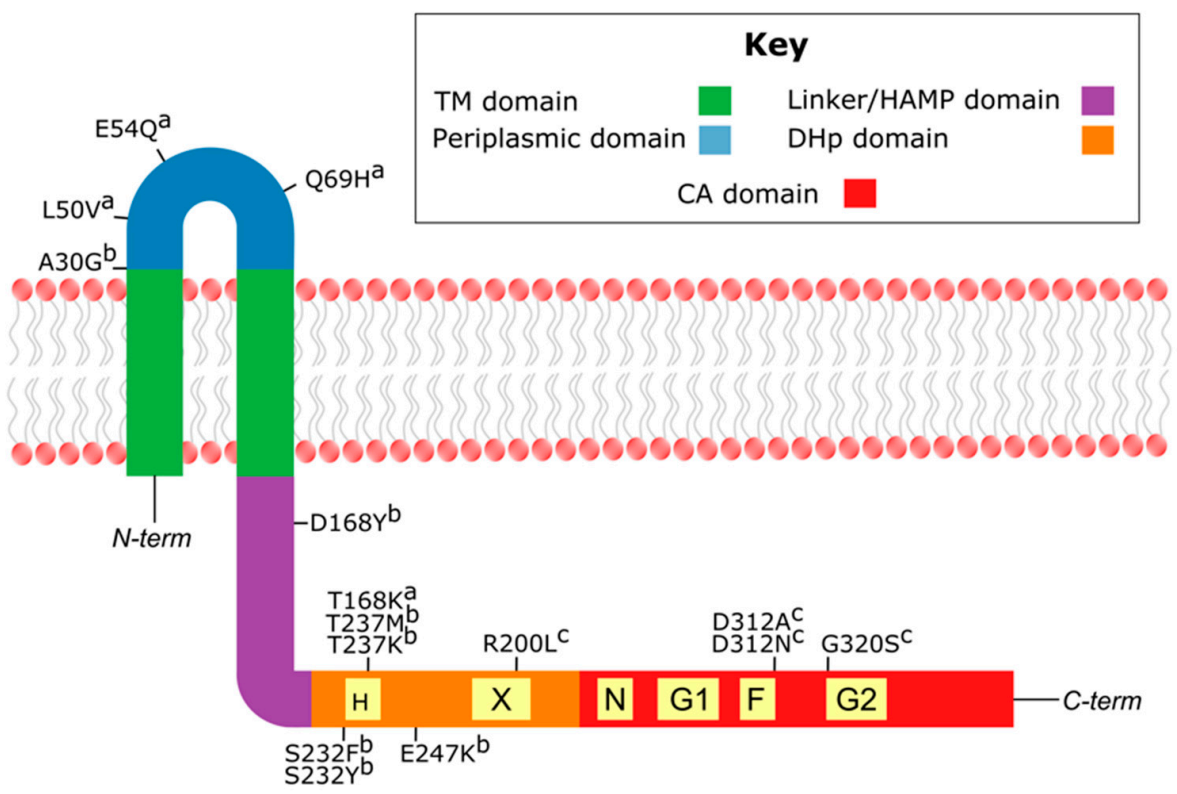

Figure 5. Domain architecture of VanS showing notable mutations affecting inducibility. Domain identities are found in the key. Conserved motifs (H, X, N, G1, G, and G2 boxes) are in yellow. Mutations are identified based on amino acid numbering of their respective VanS ortholog, designated by superscripts ( ${ }^{\mathrm{a}}$ corresponds to $\operatorname{VanS}_{\mathrm{A}},{ }^{\mathrm{b}}$ to $\operatorname{VanS}_{\mathrm{B}}$, and ${ }^{\mathrm{c}}$ to $\operatorname{VanS}_{\mathrm{C} 1}$ ).

\subsubsection{Mutations Abrogating Inducibility of Resistance}

Mutations affecting inducibility of vancomycin resistance were first identified in B-type VRE grown under teicoplanin selection [227,228,230]. Amino-acid substitutions leading to the constitutive expression of vancomycin resistance were found in the DHp domain, both in the H box (S232F, S232Y, T237K, and T237M) and immediately downstream of the $\mathrm{H}$ box (E247K) $[227,228,230]$. These mutants are also resistant to teicoplanin, as constant remodeling of peptidoglycan precursors eliminates the D-Ala-D-Ala target of teicoplanin. 
To our knowledge, the enzymatic consequences of these mutations have not been experimentally tested, but clues about their effects can be found in other HKs, in which similar substitutions within and near the $\mathrm{H}$ box abrogate phosphatase activity [231,232]. Hence, it appears likely that loss of phosphatase activity explains the constitutive expression of resistance associated with substitutions in the $\operatorname{VanS}_{\mathrm{B}} \mathrm{H}$ box. Supporting this notion, a recent mutational study of $\mathrm{VanS}_{\mathrm{A}}$ showed that substitution of residue T168 (corresponding to residue $\mathrm{T} 237$ of $\mathrm{VanS}_{\mathrm{B}}$ ) decreased $\mathrm{VanS}_{\mathrm{A}}$ phosphatase activity without affecting autophosphorylation activity [183].

Loss of all VanS activity should also lead to a constitutively resistant phenotype, as VanR can still be activated by endogenous small-molecule phosphoryl donors such as acetyl phosphate. Consistent with this idea, when a stop codon is inserted after codon 30 in $\operatorname{VanS}_{\mathrm{B}}$, constitutive resistance to both vancomycin and teicoplanin results [233].

For C-type VRE, some isolates (typically C1) express resistance constitutively, while others ( $\mathrm{C} 2 / 3$ and $\mathrm{C} 4)$ exhibit inducible resistance. The constitutive phenotype appears to map to substitutions in the DHp and CA domains. Comparison of VanS sequences from constitutive and inducible strains revealed several notable substitutions associated with constitutive behavior: R200L, D312N, D312A, and G320S [83]. Residue 200 is found in the X region, and mutations to the corresponding region of the DHp domain in EnvZ have been shown to disrupt phosphatase activity [181]. Hence, R200L appears to provide another example in which loss of VanS phosphorylation activity causes loss of inducibility.

The VanS $\mathrm{C}_{\mathrm{C}}$ substitutions D312N, D312A, and G320S fall between the F and G2 boxes of the CA domain. In the related Class-I HK EnvZ, mutations to the $\mathrm{F}$ box primarily affect phosphotransfer, while mutations to the G2 box affect all three enzymatic activities [181]. Thus, the mechanistic basis of these mutations is not yet clear. However, in a B-type clinical isolate of VRE, a six-residue deletion in the G2 box significantly disrupted only the phosphatase activity of $\operatorname{VanS}_{\mathrm{B}}$ [234]. Tentatively, then, we suggest that the D312N, D312A, and G320S mutants abrogate inducibility by decreasing $\operatorname{VanS}_{C}$ phosphatase activity.

\subsubsection{Mutations Affecting Resistance to Teicoplanin}

Certain point mutations within the sensor region cause $\mathrm{VanS}_{\mathrm{B}}$ to be activated by teicoplanin. For example, an E. faecalis strain selected for growth in the presence of teicoplanin was found to contain a A30G mutation in its VanS $\mathrm{B}_{\mathrm{B}}$ protein, which conferred teicoplanin resistance by making the resistance genes inducible by teicoplanin [227]. Residue 30 is predicted to lie at the beginning of $\operatorname{VanS}_{\mathrm{B}}$ 's periplasmic domain, suggesting that the A30G mutation may alter glycopeptide recognition by the periplasmic domain. Alternatively, it is possible that wild-type $\operatorname{VanS}_{\mathrm{B}}$ can bind to teicoplanin, but is unable to transduce this detection event to the protein's catalytic region. If this is true, the A30G mutation, lying as it does at the junction between the protein's first transmembrane helix and its periplasmic domain, may enhance the efficiency of signal transduction. Consistent with this notion, other teicoplanin-resistant $\mathrm{VanS}_{\mathrm{B}}$ mutations have been found either in the HAMP domain (D168Y) or between the HAMP and DHp domains (E221G) [227,233]. Because this region is important for signal transduction, the ability of these mutants to confer teicoplanin resistance might also reflect more efficient signal transduction in the presence of teicoplanin.

The response of A-type VRE to teicoplanin can also be altered by substitutions in the sensor region of $\mathrm{VanS}_{\mathrm{A}}$, including $\mathrm{L} 50 \mathrm{~V}, \mathrm{E} 54 \mathrm{Q}$, and Q69H, all of which fall within the predicted periplasmic domain [235]. In these variants, transcription of resistance genes cannot be induced by teicoplanin; however, they retain their inducibility by vancomycin. This is consistent with a direct-binding model in which $\mathrm{VanS}_{\mathrm{A}}$ recognizes glycopeptides via its periplasmic domain, with the ability to sense teicoplanin being specifically lost in the mutant strains. However, it is difficult to reconcile this model with the observation that vancomycin does not alter the enzymatic activities of $\mathrm{VanS}_{\mathrm{A}}$ in vitro [183], suggesting that more complex models may be required to explain glycopeptide sensing by $\operatorname{VanS}_{\mathrm{A}}$. 


\subsection{Phylogenies of VanRS Proteins}

To obtain a comprehensive view of the relationships among the enterococcal orthologs of VanS and VanR, we constructed phylogenetic trees for both proteins (Figure 6). Nonredundant amino-acid sequences for VanR and VanS were collected by searching the NCBI Identical Protein Groups database (https://www.ncbi.nlm.nih.gov/ipg; accessed on 1 December 2020) for "vanS AND enterococcus" and "vanR AND enterococcus." We also searched for VRE type-specific entries that might have been missed in the initial search. Results were filtered to exclude entries containing "partial" sequences. The VanS and VanR protein sequences from S. coelicolor were included in the final sequence analysis, as were those from the glycopeptide producer $A$. teichomyceticus, bringing the total sequence counts to 120 and 109 for VanS and VanR, respectively. S. coelicolor was included in the analysis because its VanS and VanR proteins have been extensively characterized, while $A$. teichomyceticus was included because it produces teicoplanin, and the operons conferring resistance to glycopeptide antibiotics are thought to have originated from such antibiotic-producing species [236]. The natural producer of vancomycin (Amycolatopsis orientalis) does contain a TCS that has been suggested to be involved with vancomycin resistance [237]; however, this is yet to be verified, and thus these genes were omitted from the analysis.

Conventionally, VRE are typed based on the gene sequence encoding their D-AlaD-Lac/D-Ala-D-Ser ligase, and we followed this convention to assign VRE types for our VanS and VanR protein sequences. Although several VRE types have been divided into subtypes, we chose to subtype only C-type VRE, as the $C$ subtypes are phenotypically distinct. Proteins were assigned to type $\mathrm{C} 1$ if they belonged to a strain with a vanC gene of $98-100 \%$ sequence identity to C1-type E. gallinarum strain BM4174, and $69-71 \%$ identity to C2/3 and C4 E. casseliflavus strains ATCC25788 and F32, respectively. C2/3-type proteins were classified as such if the vanC gene had $71 \%$ sequence identity to BM4174, 99-100\% to ATCC25788, and $94 \%$ to F32. Proteins were assigned to type C4 if the vanC gene had $68-71 \%$ identity to BM4174, 94-96\% to ATCC25788, and 96-98\% to F32. The first of each type to be characterized was chosen as the reference strain $[44,47,85]$.

This analysis contained proteins belonging to several vancomycin-susceptible enterococci [238-246], specifically E. faecium, E. faecalis, E. mundtii, E. alcedinis, E. sacchoralyticus, E. asini, E. sp. CU9D, E. diestrammenae, E. malodoratus, and E. florum. While these sequences were included because of their similarity to known VanRS proteins, they belong to strains that have not been explicitly identified as VRE [238,246], and which do not contain genes annotated as D-Ala-D-Lac/D-Ala-D-Ser ligases; hence it is currently unknown whether the corresponding gene products function as true VanRS proteins.

Although VRE are not typed based on their VanS and VanR sequences, it is unsurprising that in our phylogenetic analysis the VanS and VanR proteins cluster according to VRE type (Figure 6), suggesting that the regulatory proteins share common origins with the remainder of resistance operon. However, VanS and VanR do not appear to cluster on the basis of inducibility, which is the major phenotype associated with the regulatory proteins. For example, VRE types that generally express vancomycin resistance constitutively (C-, $\mathrm{D}$-, and N-types) do not all cluster near one another, though the $\mathrm{C}$ - and $\mathrm{N}$-type sequences appear to have diverged from one another relatively recently. Furthermore, sequences from VRE types in which resistance can be induced by both teicoplanin and vancomycin (A-, D-, and M-types) do not cluster either, suggesting that the regulatory proteins have arrived at their inducibility behavior by multiple avenues.

The analysis highlights the high degree of similarity between the VanR and VanS proteins from A. teichomyceticus and S. coelicolor. Type B is the VRE type for which the VanR and VanS proteins are most similar to their counterparts in A. teichomyceticus and $S$. coelicolor (Figure 6). Consistent with this observation, the VanS proteins from type-B VRE and S. coelicolor exhibit functional similarities; despite sharing only $27 \%$ sequence identity, both $\mathrm{VanS}_{\mathrm{B}}$ and $\mathrm{VanS}_{\mathrm{Sc}}$ appear to interact directly with vancomycin (Section 3.3), and both respond to vancomycin, but not to teicoplanin [247]. However, this functional similarity 
does not appear to extend to $A$. teichomyceticus, since that organism is highly resistant to teicoplanin [248]. It is therefore difficult to infer detailed regulatory mechanisms from the phylogenetic relationships between different vancomycin-resistance regulators.

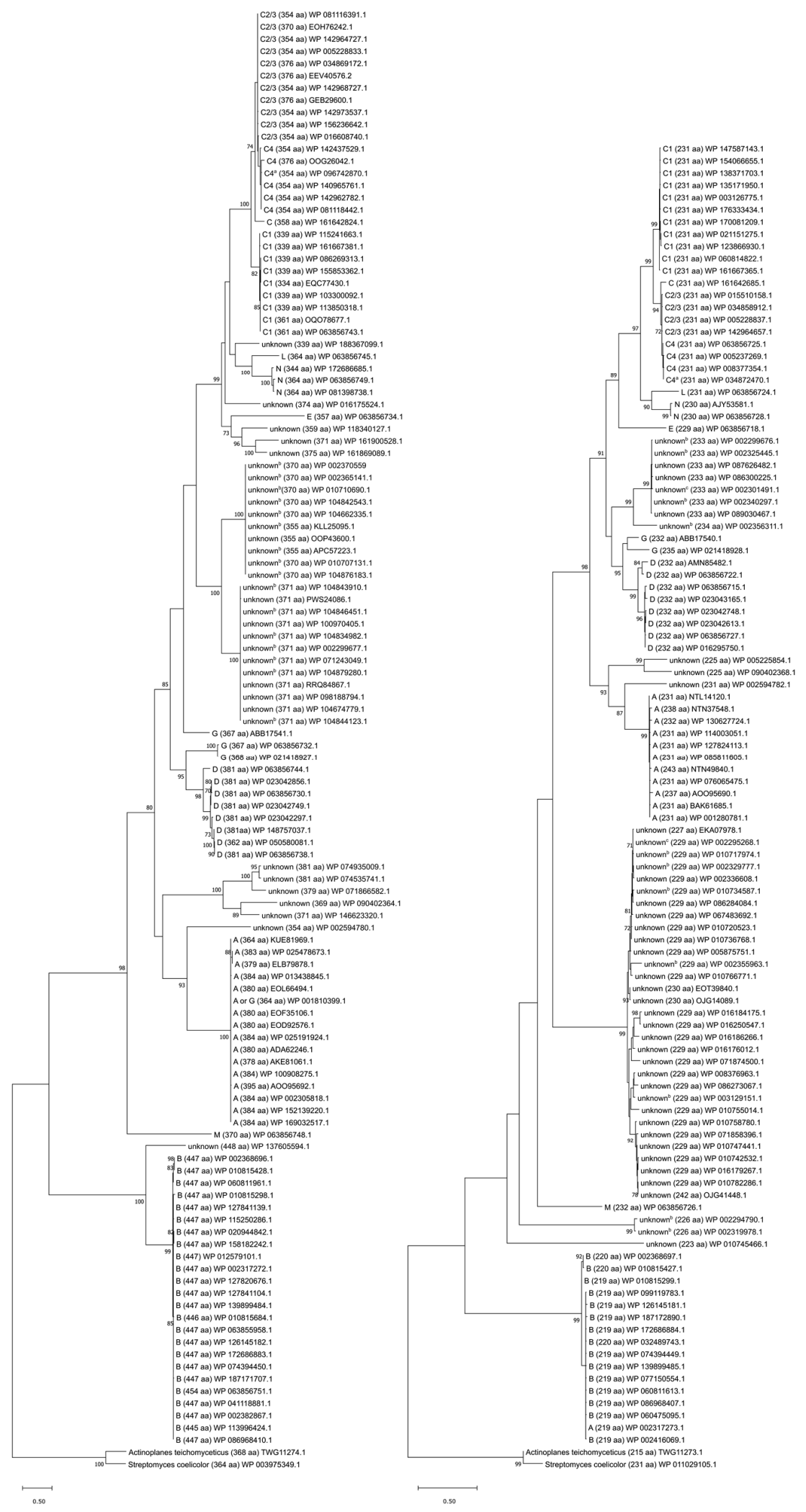

Figure 6. Evolutionary analysis of VanRS protein sequences. Trees are shown for VanS (left) and VanR (right), with VRE type, protein sequence length, and accession numbers for representative, 
nonredundant protein sequence entries being listed to the right of each branch. For the most part, C-type and -subtype proteins were not annotated as such, so they were subtyped based on nucleotide identity of van C genes to type C1 E. gallinarum strain BM4174, type C2/3 E. casseliflavus strain ATCC25788, and type C4 E. casseliflavus strain F32 (Accessions: AF162694, L29638, and EU151752.1). Trees are rooted with sequences from $S$. coelicolor and A. teichomyceticus. The scale bar represents genetic distance equivalent to 0.5 substitution per site. Trees were constructed in MEGA X [91], using 120 and 109 MUSCLE-aligned sequences for VanS and VanR, respectively [89], and employing a maximum likelihood, LG+G model [90]. 200 iterations were used, with bootstrap values indicated at branch nodes. Bootstrap values $<70 \%$ are not shown. ${ }^{\text {a }}$ Characterized by Watanabe et al. [108] as type VanC-4 despite higher nucleotide identity of the vanC gene to that of VanC-2/3-type E. casseliflavus strain ATCC25788. ${ }^{\mathrm{b}}$ VanRS proteins of unknown type belonging to Enterococcus strains for which vancomycin sensitivity was reported [73,76-78,244-248]. ${ }^{\mathrm{c}}$ VanRS proteins of unknown type belonging to Enterococcus strains for which vancomycin resistance was reported $[78,244]$.

\section{Conclusions}

VanRS was established as the regulatory TCS of vancomycin resistance expression in 1992 [124]. Since then, studies of vancomycin resistance have made considerable progress in characterizing VanRS. However, because VRE pose a significant and growing threat to human health, a better understanding is required for how expression of the resistance phenotype is regulated. This requires addressing several key questions:

1. What is the mechanism of VanS activation for clinically relevant VanS orthologs? To date, while much progress has been made toward elucidating mechanisms for VanS $S_{B}$ and $\operatorname{VanS}_{\mathrm{A}}$, definitive models still elude us; additionally, the heterogeneous nature of VRE suggests that additional mechanisms may prove relevant. Hence, there is a clear need for further biochemical and biophysical exploration of the activation mechanism(s).

2. What are the vancomycin-binding determinants for directly-activated VanS proteins such as $\operatorname{VanS}_{\mathrm{B}}$ ? It now appears evident that $\operatorname{VanS}_{\mathrm{B}}$ binds vancomycin via its periplasmic domain, leading to direct activation; however, the precise location must be mapped.

3. What are the structural consequences of activation for VanRS proteins? A recent structure of $\operatorname{VanR}_{\mathrm{Sc}}$ is the first for any VanRS protein, but structural characterization lags for the VRE orthologs of VanR and VanS. Structures of these proteins will prove invaluable in any efforts to disrupt vancomycin sensing in VRE.

Disrupting the expression of vancomycin resistance is a potentially powerful new approach to restoring vancomycin susceptibility to VRE. Antibiotic adjuvants can be imagined that would abrogate VanS's vancomycin-sensing activity or VanR's DNA-binding activity; either should restore vancomycin susceptibility to VRE. An additional possibility is the development of novel glycopeptide antibiotics that retain vancomycin's mechanism of action, but evade detection by VanS. Ultimately, however, any effort to modulate the expression of vancomycin resistance leads directly to the VanRS TCS.

Author Contributions: Conceptualization, A.A.G. and P.J.L.; investigation, A.A.G.; writing-original draft preparation, A.A.G.; writing—review and editing, A.A.G. and P.J.L.; visualization, A.A.G.; funding acquisition, P.J.L. All authors have read and agreed to the published version of the manuscript.

Funding: This research was funded by NIH-NIAID, grant number 1R01AI148679.

Institutional Review Board Statement: Not applicable.

Informed Consent Statement: Not applicable.

Conflicts of Interest: The authors declare no conflict of interest. 


\section{References}

1. Levine, D.P. Vancomycin: A history. Clin. Infect. Dis. 2006, 42, S5-S12. [CrossRef]

2. Geraci, J.E.; Heilman, F.R.; Nichols, D.R.; Wellman, W.E. Antibiotic therapy of bacterial endocarditis. VII. Vancomycin for acute micrococcal endocarditis; preliminary report. Proc. Staff Meet. Mayo Clin. 1958, 33, 172-181.

3. Geraci, J.E.; Heilman, F.R.; Nichols, D.R.; Ross, G.T.; Wellman, W.E. Some laboratory and clinical experiences with a new antibiotic, vancomycin. Proc. Staff Meet. Mayo Clin. 1956, 31, 564-582.

4. McGuire, J.M.; Wolfe, R.N.; Ziegler, D.W. Vancomycin, a new antibiotic. II. In vitro antibacterial studies. Antibiot. Annu. 1955, 3 , 612-618.

5. Traber, P.G.; Levine, D.P. Vancomycin ototoxicity in patient with normal renal function. Ann. Intern. Med. 1981, 95, 458-460. [CrossRef]

6. Rybak, M.J.; Bailey, E.M.; Warbasse, L.H. Absence of "red man syndrome" in patients being treated with vancomycin or high-dose teicoplanin. Antimicrob. Agents Chemother. 1992, 36, 1204-1207. [CrossRef]

7. Rubinstein, E.; Keynan, Y. Vancomycin revisited-60 years later. Front. Public Health 2014, 2, 217. [CrossRef]

8. Sorrell, T.C.; Packham, D.R.; Shanker, S.; Foldes, M.; Munro, R. Vancomycin therapy for methicillin-resistant Staphylococcus aureus. Ann. Intern. Med. 1982, 97, 344-350. [CrossRef]

9. Levine, D.P.; Cushing, R.D.; Jui, J.; Brown, W.J. Community-acquired methicillin-resistant Staphylococcus aureus endocarditis in the Detroit Medical Center. Ann. Intern. Med. 1982, 97, 330-338. [CrossRef]

10. Kirst, H.A.; Thompson, D.G.; Nicas, T.I. Historical yearly usage of vancomycin. Antimicrob. Agents Chemother. 1998, $42,1303-1304$. [CrossRef]

11. Fekety, R.; Shah, A.B. Diagnosis and treatment of Clostridium difficile colitis. JAMA 1993, 269, 71-75. [CrossRef]

12. Gerding, D.N. Is there a relationship between vancomycin-resistant enterococcal infection and Clostridium difficile infection? Clin. Infect. Dis. 1997, 25, S206-S210. [CrossRef]

13. Murray, B.E. The life and times of the Enterococcus. Clin. Microbiol. Rev. 1990, 3, 46-65. [CrossRef]

14. Hollenbeck, B.L.; Rice, L.B. Intrinsic and acquired resistance mechanisms in enterococcus. Virulence 2012, 3, 421-433. [CrossRef]

15. Leclercq, R.; Derlot, E.; Duval, J.; Courvalin, P. Plasmid-mediated resistance to vancomycin and teicoplanin in Enterococcus faecium. N. Engl. J. Med. 1988, 319, 157-161. [CrossRef]

16. Uttley, A.H.; Collins, C.H.; Naidoo, J.; George, R.C. Vancomycin-resistant enterococci. Lancet 1988, 1, 57-58. [CrossRef]

17. Miller, W.R.; Murray, B.E.; Rice, L.B.; Arias, C.A. Resistance in Vancomycin-Resistant Enterococci. Infect. Dis. Clin. N. Am. 2020, 34, 751-771. [CrossRef]

18. Ramos, S.; Silva, V.; Dapkevicius, M.L.E.; Igrejas, G.; Poeta, P. Enterococci, from Harmless Bacteria to a Pathogen. Microorganisms 2020, 8, 1118. [CrossRef]

19. Zhou, X.; Willems, R.J.L.; Friedrich, A.W.; Rossen, J.W.A.; Bathoorn, E. Enterococcus faecium: From microbiological insights to practical recommendations for infection control and diagnostics. Antimicrob. Resist. Infect. Control 2020, 9, 130. [CrossRef]

20. Rice, L.B. Federal funding for the study of antimicrobial resistance in nosocomial pathogens: No ESKAPE. J. Infect. Dis. 2008, 197, 1079-1081. [CrossRef]

21. WHO. Global Priority List of Antibiotic-Resistant Bacteria to Guide Research, Discovery, and Development of New Antibiotics. Available online: https://www.who.int/medicines/publications/WHO-PPL-Short_Summary_25Feb-ET_NM_WHO.pdf (accessed on 20 September 2021).

22. Jernigan, J.A.; Hatfield, K.M.; Wolford, H.; Nelson, R.E.; Olubajo, B.; Reddy, S.C.; McCarthy, N.; Paul, P.; McDonald, L.C.; Kallen, A.; et al. Multidrug-resistant bacterial infections in U.S. hospitalized patients, 2012-2017. N. Engl. J. Med. 2020, 382, 1309-1319. [CrossRef]

23. Shirvani, F.; Behzad, A.; Abdollahi, N.; Mohkam, M.; Sharifian, M.; Esfandiar, N.; Fallah, F. Frequency and co-colonization of vancomycin-resistant Enterococci and Candida in ICU-hospitalized children. New Microbes New Infect. 2021, 41, 100881. [CrossRef] [PubMed]

24. Ayobami, O.; Willrich, N.; Reuss, A.; Eckmanns, T.; Markwart, R. The ongoing challenge of vancomycin-resistant Enterococcus faecium and Enterococcus faecalis in Europe: An epidemiological analysis of bloodstream infections. Emerg. Microbes Infect. 2020, 9 , 1180-1193. [CrossRef] [PubMed]

25. Reynolds, P.E. Structure, biochemistry and mechanism of action of glycopeptide antibiotics. Eur. J. Clin. Microbiol. Infect. Dis. 1989, 8, 943-950. [CrossRef]

26. Barna, J.C.; Williams, D.H. The structure and mode of action of glycopeptide antibiotics of the vancomycin group. Annu. Rev. Microbiol. 1984, 38, 339-357. [CrossRef] [PubMed]

27. Nitanai, Y.; Kikuchi, T.; Kakoi, K.; Hanamaki, S.; Fujisawa, I.; Aoki, K. Crystal structures of the complexes between vancomycin and cell-wall precursor analogs. J. Mol. Biol. 2009, 385, 1422-1432. [CrossRef]

28. Loll, P.J.; Axelsen, P.H. The structural biology of molecular recognition by vancomycin. Annu. Rev. Biophys. Biomol. Struct. 2000, 29, 265-289. [CrossRef]

29. Handwerger, S.; Kolokathis, A. Induction of vancomycin resistance in Enterococcus faecium by inhibition of transglycosylation. FEMS Microbiol. Lett. 1990, 58, 167-170. [CrossRef]

30. Arthur, M.; Molinas, C.; Bugg, T.D.; Wright, G.D.; Walsh, C.T.; Courvalin, P. Evidence for in vivo incorporation of D-lactate into peptidoglycan precursors of vancomycin-resistant enterococci. Antimicrob. Agents Chemother. 1992, 36, 867-869. [CrossRef] 
31. Kahne, D.; Leimkuhler, C.; Lu, W.; Walsh, C. Glycopeptide and lipoglycopeptide antibiotics. Chem. Rev. 2005, 105, 425-448. [CrossRef]

32. Reynolds, P.E.; Snaith, H.A.; Maguire, A.J.; Dutka-Malen, S.; Courvalin, P. Analysis of peptidoglycan precursors in vancomycinresistant Enterococcus gallinarum BM4174. Biochem. J. 1994, 301, 5-8. [CrossRef]

33. Billot-Klein, D.; Gutmann, L.; Sable, S.; Guittet, E.; van Heijenoort, J. Modification of peptidoglycan precursors is a common feature of the low-level vancomycin-resistant VANB-type Enterococcus D366 and of the naturally glycopeptide-resistant species Lactobacillus casei, Pediococcus pentosaceus, Leuconostoc mesenteroides, and Enterococcus gallinarum. J. Bacteriol. 1994, 176, $2398-2405$. [CrossRef]

34. Grohs, P.; Gutmann, L.; Legrand, R.; Schoot, B.; Mainardi, J.L. Vancomycin resistance is associated with serine-containing peptidoglycan in Enterococcus gallinarum. J. Bacteriol. 2000, 182, 6228-6232. [CrossRef]

35. Handwerger, S.; Pucci, M.J.; Volk, K.J.; Liu, J.; Lee, M.S. The cytoplasmic peptidoglycan precursor of vancomycin-resistant Enterococcus faecalis terminates in lactate. J. Bacteriol. 1992, 174, 5982-5984. [CrossRef] [PubMed]

36. Messer, J.; Reynolds, P.E. Modified peptidoglycan precursors produced by glycopeptide-resistant enterococci. FEMS Microbiol. Lett. 1992, 73, 195-200. [CrossRef] [PubMed]

37. Billot-Klein, D.; Blanot, D.; Gutmann, L.; van Heijenoort, J. Association constants for the binding of vancomycin and teicoplanin to N-acetyl-D-alanyl-D-alanine and N-acetyl-D-alanyl-D-serine. Biochem. J 1994, 304, 1021-1022. [CrossRef] [PubMed]

38. Bugg, T.D.; Wright, G.D.; Dutka-Malen, S.; Arthur, M.; Courvalin, P.; Walsh, C.T. Molecular basis for vancomycin resistance in Enterococcus faecium BM4147: Biosynthesis of a depsipeptide peptidoglycan precursor by vancomycin resistance proteins VanH and VanA. Biochemistry 1991, 30, 10408-10415. [CrossRef] [PubMed]

39. Bugg, T.D.; Dutka-Malen, S.; Arthur, M.; Courvalin, P.; Walsh, C.T. Identification of vancomycin resistance protein VanA as a D-alanine:D-alanine ligase of altered substrate specificity. Biochemistry 1991, 30, 2017-2021. [CrossRef]

40. Arias, C.A.; Martin-Martinez, M.; Blundell, T.L.; Arthur, M.; Courvalin, P.; Reynolds, P.E. Characterization and modelling of VanT: A novel, membrane-bound, serine racemase from vancomycin-resistant Enterococcus gallinarum BM4174. Mol. Microbiol. 1999, 31, 1653-1664. [CrossRef]

41. Brisson-Noel, A.; Dutka-Malen, S.; Molinas, C.; Leclercq, R.; Courvalin, P. Cloning and heterospecific expression of the resistance determinant vanA encoding high-level resistance to glycopeptides in Enterococcus faecium BM4147. Antimicrob. Agents Chemother. 1990, 34, 924-927. [CrossRef]

42. Evers, S.; Sahm, D.F.; Courvalin, P. The vanB gene of vancomycin-resistant Enterococcus faecalis V583 is structurally related to genes encoding D-Ala:D-Ala ligases and glycopeptide-resistance proteins VanA and VanC. Gene 1993, 124, 143-144. [CrossRef]

43. Quintiliani, R., Jr.; Evers, S.; Courvalin, P. The vanB gene confers various levels of self-transferable resistance to vancomycin in enterococci. J. Infect. Dis. 1993, 167, 1220-1223. [CrossRef]

44. Dutka-Malen, S.; Molinas, C.; Arthur, M.; Courvalin, P. Sequence of the vanC gene of Enterococcus gallinarum BM4174 encoding a D-alanine:D-alanine ligase-related protein necessary for vancomycin resistance. Gene 1992, 112, 53-58. [CrossRef]

45. Perichon, B.; Reynolds, P.; Courvalin, P. VanD-type glycopeptide-resistant Enterococcus faecium BM4339. Antimicrob. Agents Chemother. 1997, 41, 2016-2018. [CrossRef] [PubMed]

46. Park, I.S.; Lin, C.H.; Walsh, C.T. Bacterial resistance to vancomycin: Overproduction, purification, and characterization of VanC2 from Enterococcus casseliflavus as a D-Ala-D-Ser ligase. Proc. Natl. Acad. Sci. USA 1997, 94, 10040-10044. [CrossRef]

47. Navarro, F.; Courvalin, P. Analysis of genes encoding D-alanine-D-alanine ligase-related enzymes in Enterococcus casseliflavus and Enterococcus flavescens. Antimicrob. Agents Chemother. 1994, 38, 1788-1793. [CrossRef]

48. Abadia Patino, L.; Courvalin, P.; Perichon, B. vanE gene cluster of vancomycin-resistant Enterococcus faecalis BM4405. J. Bacteriol. 2002, 184, 6457-6464. [CrossRef] [PubMed]

49. Boyd, D.A.; Cabral, T.; Van Caeseele, P.; Wylie, J.; Mulvey, M.R. Molecular characterization of the vanE gene cluster in vancomycinresistant Enterococcus faecalis N00-410 isolated in Canada. Antimicrob. Agents Chemother. 2002, 46, 1977-1979. [CrossRef]

50. McKessar, S.J.; Berry, A.M.; Bell, J.M.; Turnidge, J.D.; Paton, J.C. Genetic characterization of vanG, a novel vancomycin resistance locus of Enterococcus faecalis. Antimicrob. Agents Chemother. 2000, 44, 3224-3228. [CrossRef]

51. Meziane-Cherif, D.; Saul, F.A.; Haouz, A.; Courvalin, P. Structural and functional characterization of VanG D-Ala:D-Ser ligase associated with vancomycin resistance in Enterococcus faecalis. J. Biol. Chem. 2012, 287, 37583-37592. [CrossRef]

52. Xu, X.; Lin, D.; Yan, G.; Ye, X.; Wu, S.; Guo, Y.; Zhu, D.; Hu, F.; Zhang, Y.; Wang, F.; et al. vanM, a new glycopeptide resistance gene cluster found in Enterococcus faecium. Antimicrob. Agents Chemother. 2010, 54, 4643-4647. [CrossRef]

53. Lebreton, F.; Depardieu, F.; Bourdon, N.; Fines-Guyon, M.; Berger, P.; Camiade, S.; Leclercq, R.; Courvalin, P.; Cattoir, V. D-Ala-DSer VanN-type transferable vancomycin resistance in Enterococcus faecium. Antimicrob. Agents Chemother. 2011, 55, 4606-4612. [CrossRef]

54. Healy, V.L.; Lessard, I.A.; Roper, D.I.; Knox, J.R.; Walsh, C.T. Vancomycin resistance in enterococci: Reprogramming of the D-ala-D-Ala ligases in bacterial peptidoglycan biosynthesis. Chem. Biol. 2000, 7, R109-R119. [CrossRef]

55. Reynolds, P.E.; Depardieu, F.; Dutka-Malen, S.; Arthur, M.; Courvalin, P. Glycopeptide resistance mediated by enterococcal transposon Tn1546 requires production of VanX for hydrolysis of D-alanyl-D-alanine. Mol. Microbiol. 1994, 13, 1065-1070. [CrossRef] [PubMed]

56. Arias, C.A.; Courvalin, P.; Reynolds, P.E. vanC cluster of vancomycin-resistant Enterococcus gallinarum BM4174. Antimicrob. Agents Chemother. 2000, 44, 1660-1666. [CrossRef] 
57. Reynolds, P.E.; Arias, C.A.; Courvalin, P. Gene vanXYC encodes D,D-dipeptidase (VanX) and D,D-carboxypeptidase (VanY) activities in vancomycin-resistant Enterococcus gallinarum BM4174. Mol. Microbiol. 1999, 34, 341-349. [CrossRef] [PubMed]

58. Arthur, M.; Courvalin, P. Genetics and mechanisms of glycopeptide resistance in enterococci. Antimicrob. Agents Chemother. 1993, 37, 1563-1571. [CrossRef]

59. Arthur, M.; Reynolds, P.; Courvalin, P. Glycopeptide resistance in enterococci. Trends Microbiol. 1996, 4, 401-407. [CrossRef]

60. Reynolds, P.E. Control of peptidoglycan synthesis in vancomycin-resistant enterococci: D,D-peptidases and D,D-carboxypeptidases. Cell Mol. Life Sci. 1998, 54, 325-331. [CrossRef] [PubMed]

61. Walsh, C.T.; Fisher, S.L.; Park, I.S.; Prahalad, M.; Wu, Z. Bacterial resistance to vancomycin: Five genes and one missing hydrogen bond tell the story. Chem. Biol. 1996, 3, 21-28. [CrossRef]

62. Gholizadeh, Y.; Courvalin, P. Acquired and intrinsic glycopeptide resistance in enterococci. Int. J. Antimicrob. Agents 2000, 16, S11-S17. [CrossRef]

63. Woodford, N. Epidemiology of the genetic elements responsible for acquired glycopeptide resistance in enterococci. Microb. Drug Resist. 2001, 7, 229-236. [CrossRef] [PubMed]

64. Reynolds, P.E.; Courvalin, P. Vancomycin resistance in enterococci due to synthesis of precursors terminating in D-alanyl-D-serine. Antimicrob. Agents Chemother. 2005, 49, 21-25. [CrossRef] [PubMed]

65. Stogios, P.J.; Savchenko, A. Molecular mechanisms of vancomycin resistance. Protein Sci. 2020, 29, 654-669. [CrossRef] [PubMed]

66. Depardieu, F.; Perichon, B.; Courvalin, P. Detection of the van alphabet and identification of enterococci and staphylococci at the species level by multiplex PCR. J. Clin. Microbiol. 2004, 42, 5857-5860. [CrossRef] [PubMed]

67. Xavier, B.B.; Coppens, J.; De Koster, S.; Rajakani, S.G.; Van Goethem, S.; Mzougui, S.; Anantharajah, A.; Lammens, C.; Loens, K.; Glupczynski, Y.; et al. Novel vancomycin resistance gene cluster in Enterococcus faecium ST1486, Belgium, June 2021. Eurosurveillance 2021, 26, 2100767. [CrossRef] [PubMed]

68. Al-Obeid, S.; Collatz, E.; Gutmann, L. Mechanism of resistance to vancomycin in Enterococcus faecium D366 and Enterococcus faecalis A256. Antimicrob. Agents Chemother. 1990, 34, 252-256. [CrossRef]

69. Leclercq, R.; Derlot, E.; Weber, M.; Duval, J.; Courvalin, P. Transferable vancomycin and teicoplanin resistance in Enterococcus faecium. Antimicrob. Agents Chemother. 1989, 33, 10-15. [CrossRef]

70. Nicas, T.I.; Wu, C.Y.; Hobbs, J.N., Jr.; Preston, D.A.; Allen, N.E. Characterization of vancomycin resistance in Enterococcus faecium and Enterococcus faecalis. Antimicrob. Agents Chemother. 1989, 33, 1121-1124. [CrossRef]

71. Shlaes, D.M.; Al-Obeid, S.; Shlaes, J.H.; Boisivon, A.; Williamson, R. Inducible, transferable resistance to vancomycin in Enterococcus faecium, D399. J. Antimicrob. Chemother. 1989, 23, 503-508. [CrossRef]

72. Uttley, A.H.; George, R.C.; Naidoo, J.; Woodford, N.; Johnson, A.P.; Collins, C.H.; Morrison, D.; Gilfillan, A.J.; Fitch, L.E.; Heptonstall, J. High-level vancomycin-resistant enterococci causing hospital infections. Epidemiol. Infect. 1989, 103, $173-181$. [CrossRef]

73. Billot-Klein, D.; Gutmann, L.; Collatz, E.; van Heijenoort, J. Analysis of peptidoglycan precursors in vancomycin-resistant enterococci. Antimicrob. Agents Chemother. 1992, 36, 1487-1490. [CrossRef] [PubMed]

74. Evers, S.; Reynolds, P.E.; Courvalin, P. Sequence of the vanB and ddl genes encoding D-alanine:D-lactate and D-alanine:D-alanine ligases in vancomycin-resistant Enterococcus faecalis V583. Gene 1994, 140, 97-102. [CrossRef]

75. Rice, L.B.; Carias, L.L.; Donskey, C.L.; Rudin, S.D. Transferable, plasmid-mediated vanB-type glycopeptide resistance in Enterococcus faecium. Antimicrob. Agents Chemother. 1998, 42, 963-964. [CrossRef] [PubMed]

76. Garnier, F.; Taourit, S.; Glaser, P.; Courvalin, P.; Galimand, M. Characterization of transposon Tn1549, conferring VanB-type resistance in Enterococcus spp. Microbiology 2000, 146, 1481-1489. [CrossRef] [PubMed]

77. Sahm, D.F.; Kissinger, J.; Gilmore, M.S.; Murray, P.R.; Mulder, R.; Solliday, J.; Clarke, B. In vitro susceptibility studies of vancomycin-resistant Enterococcus faecalis. Antimicrob. Agents Chemother. 1989, 33, 1588-1591. [CrossRef]

78. Billot-Klein, D.; Shlaes, D.; Bryant, D.; Bell, D.; van Heijenoort, J.; Gutmann, L. Peptidoglycan structure of Enterococcus faecium expressing vancomycin resistance of the VanB type. Biochem. J. 1996, 313, 711-715. [CrossRef]

79. Williamson, R.; Al-Obeid, S.; Shlaes, J.H.; Goldstein, F.W.; Shlaes, D.M. Inducible resistance to vancomycin in Enterococcus faecium D366. J. Infect. Dis. 1989, 159, 1095-1104. [CrossRef]

80. Leclercq, R.; Dutka-Malen, S.; Duval, J.; Courvalin, P. Vancomycin resistance gene vanC is specific to Enterococcus gallinarum. Antimicrob. Agents Chemother. 1992, 36, 2005-2008. [CrossRef]

81. Toye, B.; Shymanski, J.; Bobrowska, M.; Woods, W.; Ramotar, K. Clinical and epidemiological significance of enterococci intrinsically resistant to vancomycin (possessing the vanC genotype). J. Clin. Microbiol. 1997, 35, 3166-3170. [CrossRef]

82. Sahm, D.F.; Free, L.; Handwerger, S. Inducible and constitutive expression of vanC-1-encoded resistance to vancomycin in Enterococcus gallinarum. Antimicrob. Agents Chemother. 1995, 39, 1480-1484. [CrossRef] [PubMed]

83. Panesso, D.; Abadia-Patino, L.; Vanegas, N.; Reynolds, P.E.; Courvalin, P.; Arias, C.A. Transcriptional analysis of the vanC cluster from Enterococcus gallinarum strains with constitutive and inducible vancomycin resistance. Antimicrob. Agents Chemother. 2005, 49, 1060-1066. [CrossRef] [PubMed]

84. Vincent, S.; Minkler, P.; Bincziewski, B.; Etter, L.; Shlaes, D.M. Vancomycin resistance in Enterococcus gallinarum. Antimicrob. Agents Chemother. 1992, 36, 1392-1399. [CrossRef] 
85. Watanabe, S.; Kobayashi, N.; Quinones, D.; Hayakawa, S.; Nagashima, S.; Uehara, N.; Watanabe, N. Genetic diversity of the low-level vancomycin resistance gene vanC-2/vanC-3 and identification of a novel vanC subtype (vanC-4) in Enterococcus casseliflavus. Microb. Drug Resist. 2009, 15, 1-9. [CrossRef] [PubMed]

86. Reid, K.C.; Cockerill, I.F.; Patel, R. Clinical and epidemiological features of Enterococcus casseliflavus/flavescens and Enterococcus gallinarum bacteremia: A report of 20 cases. Clin. Infect. Dis. 2001, 32, 1540-1546. [CrossRef]

87. Depardieu, F.; Reynolds, P.E.; Courvalin, P. VanD-type vancomycin-resistant Enterococcus faecium 10/96A. Antimicrob. Agents Chemother. 2003, 47,7-18. [CrossRef] [PubMed]

88. Casadewall, B.; Courvalin, P. Characterization of the vanD glycopeptide resistance gene cluster from Enterococcus faecium BM4339. J. Bacteriol. 1999, 181, 3644-3648. [CrossRef] [PubMed]

89. Ostrowsky, B.E.; Clark, N.C.; Thauvin-Eliopoulos, C.; Venkataraman, L.; Samore, M.H.; Tenover, F.C.; Eliopoulos, G.M.; Moellering, R.C., Jr.; Gold, H.S. A cluster of VanD vancomycin-resistant Enterococcus faecium: Molecular characterization and clinical epidemiology. J. Infect. Dis. 1999, 180, 1177-1185. [CrossRef]

90. Perichon, B.; Casadewall, B.; Reynolds, P.; Courvalin, P. Glycopeptide-resistant Enterococcus faecium BM4416 is a VanD-type strain with an impaired D-Alanine:D-Alanine ligase. Antimicrob. Agents Chemother. 2000, 44, 1346-1348. [CrossRef]

91. Dalla Costa, L.M.; Reynolds, P.E.; Souza, H.A.; Souza, D.C.; Palepou, M.F.; Woodford, N. Characterization of a divergent vanD-type resistance element from the first glycopeptide-resistant strain of Enterococcus faecium isolated in Brazil. Antimicrob. Agents Chemother. 2000, 44, 3444-3446. [CrossRef]

92. Boyd, D.A.; Conly, J.; Dedier, H.; Peters, G.; Robertson, L.; Slater, E.; Mulvey, M.R. Molecular characterization of the vanD gene cluster and a novel insertion element in a vancomycin-resistant enterococcus isolated in Canada. J. Clin. Microbiol. 2000, 38, 2392-2394. [CrossRef]

93. Fines, M.; Perichon, B.; Reynolds, P.; Sahm, D.F.; Courvalin, P. VanE, a new type of acquired glycopeptide resistance in Enterococcus faecalis BM4405. Antimicrob. Agents Chemother. 1999, 43, 2161-2164. [CrossRef] [PubMed]

94. Abadia-Patino, L.; Christiansen, K.; Bell, J.; Courvalin, P.; Perichon, B. VanE-type vancomycin-resistant Enterococcus faecalis clinical isolates from Australia. Antimicrob. Agents Chemother. 2004, 48, 4882-4885. [CrossRef] [PubMed]

95. Van Caeseele, P.; Giercke, S.; Wylie, J.; Boyd, D.; Mulvey, M.; Amin, S.; Ofner-Agostini, M. Identification of the first vancomycinresistant Enterococcus faecalis harbouring vanE in Canada. Can. Commun. Dis. Rep. 2001, 27, 101-104. [PubMed]

96. Depardieu, F.; Bonora, M.G.; Reynolds, P.E.; Courvalin, P. The vanG glycopeptide resistance operon from Enterococcus faecalis revisited. Mol. Microbiol. 2003, 50, 931-948. [CrossRef] [PubMed]

97. Boyd, D.A.; Du, T.; Hizon, R.; Kaplen, B.; Murphy, T.; Tyler, S.; Brown, S.; Jamieson, F.; Weiss, K.; Mulvey, M.R. VanG-type vancomycin-resistant Enterococcus faecalis strains isolated in Canada. Antimicrob. Agents Chemother. 2006, 50, 2217-2221. [CrossRef]

98. Sassi, M.; Guerin, F.; Lesec, L.; Isnard, C.; Fines-Guyon, M.; Cattoir, V.; Giard, J.C. Genetic characterization of a VanG-type vancomycin-resistant Enterococcus faecium clinical isolate. J. Antimicrob. Chemother. 2018, 73, 852-855. [CrossRef]

99. Boyd, D.A.; Willey, B.M.; Fawcett, D.; Gillani, N.; Mulvey, M.R. Molecular characterization of Enterococcus faecalis N06-0364 with low-level vancomycin resistance harboring a novel D-Ala-D-Ser gene cluster, vanL. Antimicrob. Agents Chemother. 2008, 52, 2667-2672. [CrossRef]

100. He, Y.H.; Ruan, G.J.; Hao, H.; Xue, F.; Ma, Y.K.; Zhu, S.N.; Zheng, B. Real-time PCR for the rapid detection of vanA, vanB and vanM genes. J. Microbiol. Immunol. Infect. 2019, 53, 746-750. [CrossRef]

101. Chen, C.; Sun, J.; Guo, Y.; Lin, D.; Guo, Q.; Hu, F.; Zhu, D.; Xu, X.; Wang, M. High prevalence of vanM in vancomycin-resistant Enterococcus faecium isolates from Shanghai, China. Antimicrob. Agents Chemother. 2015, 59, 7795-7798. [CrossRef]

102. Nomura, T.; Tanimoto, K.; Shibayama, K.; Arakawa, Y.; Fujimoto, S.; Ike, Y.; Tomita, H. Identification of VanN-type vancomycin resistance in an Enterococcus faecium isolate from chicken meat in Japan. Antimicrob. Agents Chemother. 2012, 56, 6389-6392. [CrossRef] [PubMed]

103. U. S. Centers for Disease Control and Prevention. Antibiotic Resistance Threats in the United States 2019. Available online: https://www.cdc.gov/hai/settings/lab/vreclinical-laboratory.html (accessed on 22 August 2021).

104. Facklam, R.R.; Collins, M.D. Identification of Enterococcus species isolated from human infections by a conventional test scheme. J. Clin. Microbiol. 1989, 27, 731-734. [CrossRef] [PubMed]

105. Pompei, R.; Berlutti, F.; Thaller, M.C.; Ingianni, A.; Cortis, G.; Dainelli, B. Enterococcus flavescens sp. nov., a new species of enterococci of clinical origin. Int. J. Syst. Bacteriol. 1992, 42, 365-369. [CrossRef] [PubMed]

106. Monticelli, J.; Knezevich, A.; Luzzati, R.; Di Bella, S. Clinical management of non-faecium non-faecalis vancomycin-resistant enterococci infection. Focus on Enterococcus gallinarum and Enterococcus casseliflavus/flavescens. J. Infect. Chemother. 2018, 24, 237-246. [CrossRef] [PubMed]

107. Nieto, M.; Perkins, H.R. Modifications of the acyl-D-alanyl-D-alanine terminus affecting complex-formation with vancomycin. Biochem. J. 1971, 123, 789-803. [CrossRef] [PubMed]

108. Shlaes, D.M.; Etter, L.; Gutmann, L. Synergistic killing of vancomycin-resistant enterococci of classes A, B, and C by combinations of vancomycin, penicillin, and gentamicin. Antimicrob. Agents Chemother. 1991, 35, 776-779. [CrossRef] [PubMed]

109. Courvalin, P. Resistance of enterococci to glycopeptides. Antimicrob. Agents Chemother. 1990, 34, 2291-2296. [CrossRef]

110. Casadewall, B.; Reynolds, P.E.; Courvalin, P. Regulation of expression of the vanD glycopeptide resistance gene cluster from Enterococcus faecium BM4339. J. Bacteriol. 2001, 183, 3436-3446. [CrossRef] 
111. Swenson, J.M.; Hill, B.C.; Thornsberry, C. Problems with the disk diffusion test for detection of vancomycin resistance in enterococci. J. Clin. Microbiol. 1989, 27, 2140-2142. [CrossRef]

112. Vincent, S.; Knight, R.G.; Green, M.; Sahm, D.F.; Shlaes, D.M. Vancomycin susceptibility and identification of motile enterococci. J. Clin. Microbiol. 1991, 29, 2335-2337. [CrossRef]

113. Dutta, I.; Reynolds, P.E. Biochemical and genetic characterization of the vanC-2 vancomycin resistance gene cluster of Enterococcus casseliflavus ATCC 25788. Antimicrob. Agents Chemother. 2002, 46, 3125-3132. [CrossRef]

114. Dutka-Malen, S.; Leclercq, R.; Coutant, V.; Duval, J.; Courvalin, P. Phenotypic and genotypic heterogeneity of glycopeptide resistance determinants in gram-positive bacteria. Antimicrob. Agents Chemother. 1990, 34, 1875-1879. [CrossRef]

115. Clark, N.C.; Teixeira, L.M.; Facklam, R.R.; Tenover, F.C. Detection and differentiation of vanC-1, vanC-2, and vanC-3 glycopeptide resistance genes in enterococci. J. Clin. Microbiol. 1998, 36, 2294-2297. [CrossRef]

116. Palladino, S.; Kay, I.D.; Costa, A.M.; Lambert, E.J.; Flexman, J.P. Real-time PCR for the rapid detection of vanA and vanB genes. Diagn. Microbiol. Infect. Dis. 2003, 45, 81-84. [CrossRef]

117. Palladino, S.; Kay, I.D.; Flexman, J.P.; Boehm, I.; Costa, A.M.; Lambert, E.J.; Christiansen, K.J. Rapid detection of vanA and vanB genes directly from clinical specimens and enrichment broths by real-time multiplex PCR assay. J. Clin. Microbiol. 2003, 41, 2483-2486. [CrossRef] [PubMed]

118. Clark, N.C.; Cooksey, R.C.; Hill, B.C.; Swenson, J.M.; Tenover, F.C. Characterization of glycopeptide-resistant enterococci from U.S. hospitals. Antimicrob. Agents Chemother. 1993, 37, 2311-2317. [CrossRef]

119. Kawalec, M.; Gniadkowski, M.; Zielinska, U.; Klos, W.; Hryniewicz, W. Vancomycin-resistant Enterococcus faecium strain carrying the vanB2 gene variant in a Polish hospital. J. Clin. Microbiol. 2001, 39, 811-815. [CrossRef] [PubMed]

120. Dahl, K.H.; Simonsen, G.S.; Olsvik, O.; Sundsfjord, A. Heterogeneity in the vanB gene cluster of genomically diverse clinical strains of vancomycin-resistant enterococci. Antimicrob. Agents Chemother. 1999, 43, 1105-1110. [CrossRef] [PubMed]

121. Dahl, K.H.; Lundblad, E.W.; Rokenes, T.P.; Olsvik, O.; Sundsfjord, A. Genetic linkage of the vanB2 gene cluster to Tn5382 in vancomycin-resistant enterococci and characterization of two novel insertion sequences. Microbiology 2000, 146, 1469-1479. [CrossRef] [PubMed]

122. McGregor, K.F.; Young, H.K. Identification and characterization of vanB2 glycopeptide resistance elements in enterococci isolated in Scotland. Antimicrob. Agents Chemother. 2000, 44, 2341-2348. [CrossRef] [PubMed]

123. Boyd, D.A.; Kibsey, P.; Roscoe, D.; Mulvey, M.R. Enterococcus faecium N03-0072 carries a new VanD-type vancomycin resistance determinant: Characterization of the VanD5 operon. J. Antimicrob. Chemother. 2004, 54, 680-683. [CrossRef]

124. Arthur, M.; Molinas, C.; Courvalin, P. The VanS-VanR two-component regulatory system controls synthesis of depsipeptide peptidoglycan precursors in Enterococcus faecium BM4147. J. Bacteriol. 1992, 174, 2582-2591. [CrossRef]

125. Arthur, M.; Molinas, C.; Courvalin, P. Sequence of the vanY gene required for production of a vancomycin-inducible D,Dcarboxypeptidase in Enterococcus faecium BM4147. Gene 1992, 120, 111-114. [CrossRef]

126. Arthur, M.; Molinas, C.; Depardieu, F.; Courvalin, P. Characterization of Tn1546, a Tn3-related transposon conferring glycopeptide resistance by synthesis of depsipeptide peptidoglycan precursors in Enterococcus faecium BM4147. J. Bacteriol. 1993, 175, 117-127. [CrossRef] [PubMed]

127. Gutmann, L.; Billot-Klein, D.; al-Obeid, S.; Klare, I.; Francoual, S.; Collatz, E.; van Heijenoort, J. Inducible carboxypeptidase activity in vancomycin-resistant enterococci. Antimicrob. Agents Chemother. 1992, 36, 77-80. [CrossRef]

128. Wright, G.D.; Molinas, C.; Arthur, M.; Courvalin, P.; Walsh, C.T. Characterization of vanY, a D,D-carboxypeptidase from vancomycin-resistant Enterococcus faecium BM4147. Antimicrob. Agents Chemother. 1992, 36, 1514-1518. [CrossRef] [PubMed]

129. Evers, S.; Courvalin, P. Regulation of VanB-type vancomycin resistance gene expression by the VanS(B)-VanR (B) two-component regulatory system in Enterococcus faecalis V583. J. Bacteriol. 1996, 178, 1302-1309. [CrossRef]

130. Arthur, M.; Depardieu, F.; Molinas, C.; Reynolds, P.; Courvalin, P. The vanZ gene of Tn1546 from Enterococcus faecium BM4147 confers resistance to teicoplanin. Gene 1995, 154, 87-92. [CrossRef]

131. Arthur, M.; Depardieu, F.; Reynolds, P.; Courvalin, P. Quantitative analysis of the metabolism of soluble cytoplasmic peptidoglycan precursors of glycopeptide-resistant enterococci. Mol. Microbiol. 1996, 21, 33-44. [CrossRef]

132. Vimberg, V.; Zieglerova, L.; Buriankova, K.; Branny, P.; Balikova Novotna, G. VanZ Reduces the binding of lipoglycopeptide antibiotics to Staphylococcus aureus and Streptococcus pneumoniae cells. Front. Microbiol. 2020, 11, 566. [CrossRef]

133. Handwerger, S.; Skoble, J. Identification of chromosomal mobile element conferring high-level vancomycin resistance in Enterococcus faecium. Antimicrob. Agents Chemother. 1995, 39, 2446-2453. [CrossRef]

134. Handwerger, S.; Pucci, M.J.; Kolokathis, A. Vancomycin resistance is encoded on a pheromone response plasmid in Enterococcus faecium 228. Antimicrob. Agents Chemother. 1990, 34, 358-360. [CrossRef] [PubMed]

135. Noble, W.C.; Virani, Z.; Cree, R.G. Co-transfer of vancomycin and other resistance genes from Enterococcus faecalis NCTC 12201 to Staphylococcus aureus. FEMS Microbiol. Lett. 1992, 72, 195-198. [CrossRef] [PubMed]

136. Hashimoto, Y.; Kita, I.; Suzuki, M.; Hirakawa, H.; Ohtaki, H.; Tomita, H. First report of the local spread of vancomycin-resistant Enterococci ascribed to the interspecies transmission of a vanA gene cluster-carrying linear plasmid. mSphere 2020, 5, e00102-20. [CrossRef] [PubMed]

137. Heaton, M.P.; Discotto, L.F.; Pucci, M.J.; Handwerger, S. Mobilization of vancomycin resistance by transposon-mediated fusion of a VanA plasmid with an Enterococcus faecium sex pheromone-response plasmid. Gene 1996, 171, 9-17. [CrossRef] 
138. Sivertsen, A.; Pedersen, T.; Larssen, K.W.; Bergh, K.; Ronning, T.G.; Radtke, A.; Hegstad, K. A silenced vanA gene cluster on a transferable plasmid caused an outbreak of vancomycin-variable Enterococci. Antimicrob. Agents Chemother. 2016, 60, $4119-4127$. [CrossRef]

139. Werner, G.; Klare, I.; Witte, W. Large conjugative vanA plasmids in vancomycin-resistant Enterococcus faecium. J. Clin. Microbiol. 1999, 37, 2383-2384. [CrossRef]

140. Wright, G.D. Antibiotic adjuvants: Rescuing antibiotics from resistance. Trends Microbiol. 2016, 24, 928. [CrossRef]

141. Capra, E.J.; Laub, M.T. Evolution of two-component signal transduction systems. Annu. Rev. Microbiol. 2012, 66, 325-347. [CrossRef]

142. Wuichet, K.; Cantwell, B.J.; Zhulin, I.B. Evolution and phyletic distribution of two-component signal transduction systems. Curr. Opin. Microbiol. 2010, 13, 219-225. [CrossRef]

143. Schaller, G.E.; Shiu, S.H.; Armitage, J.P. Two-component systems and their co-option for eukaryotic signal transduction. Curr. Biol. 2011, 21, R320-R330. [CrossRef]

144. Defosse, T.A.; Sharma, A.; Mondal, A.K.; Duge de Bernonville, T.; Latge, J.P.; Calderone, R.; Giglioli-Guivarc'h, N.; Courdavault, V.; Clastre, M.; Papon, N. Hybrid histidine kinases in pathogenic fungi. Mol. Microbiol. 2015, 95, 914-924. [CrossRef]

145. Osakabe, Y.; Yamaguchi-Shinozaki, K.; Shinozaki, K.; Tran, L.S. Sensing the environment: Key roles of membrane-localized kinases in plant perception and response to abiotic stress. J. Exp. Bot. 2013, 64, 445-458. [CrossRef]

146. Mascher, T.; Helmann, J.D.; Unden, G. Stimulus perception in bacterial signal-transducing histidine kinases. Microbiol. Mol. Biol. Rev. 2006, 70, 910-938. [CrossRef]

147. Ulijasz, A.T.; Grenader, A.; Weisblum, B. A vancomycin-inducible lacZ reporter system in Bacillus subtilis: Induction by antibiotics that inhibit cell wall synthesis and by lysozyme. J. Bacteriol. 1996, 178, 6305-6309. [CrossRef]

148. Arthur, M.; Depardieu, F.; Gerbaud, G.; Galimand, M.; Leclercq, R.; Courvalin, P. The VanS sensor negatively controls VanRmediated transcriptional activation of glycopeptide resistance genes of Tn1546 and related elements in the absence of induction. J. Bacteriol. 1997, 179, 97-106. [CrossRef]

149. Wright, G.D.; Holman, T.R.; Walsh, C.T. Purification and characterization of VanR and the cytosolic domain of VanS: A twocomponent regulatory system required for vancomycin resistance in Enterococcus faecium BM4147. Biochemistry 1993, 32, 5057-5063. [CrossRef] [PubMed]

150. Holman, T.R.; Wu, Z.; Wanner, B.L.; Walsh, C.T. Identification of the DNA-binding site for the phosphorylated VanR protein required for vancomycin resistance in Enterococcus faecium. Biochemistry 1994, 33, 4625-4631. [CrossRef] [PubMed]

151. Depardieu, F.; Courvalin, P.; Kolb, A. Binding sites of VanRB and sigma70 RNA polymerase in the vanB vancomycin resistance operon of Enterococcus faecium BM4524. Mol. Microbiol. 2005, 57, 550-564. [CrossRef] [PubMed]

152. Haldimann, A.; Fisher, S.L.; Daniels, L.L.; Walsh, C.T.; Wanner, B.L. Transcriptional regulation of the Enterococcus faecium BM4147 vancomycin resistance gene cluster by the VanS-VanR two-component regulatory system in Escherichia coli K-12. J. Bacteriol. 1997, 179, 5903-5913. [CrossRef] [PubMed]

153. Arthur, M.; Depardieu, F.; Courvalin, P. Regulated interactions between partner and non-partner sensors and response regulators that control glycopeptide resistance gene expression in enterococci. Microbiology 1999, 145, 1849-1858. [CrossRef]

154. Kim, D.J.; Forst, S. Genomic analysis of the histidine kinase family in bacteria and archaea. Microbiology 2001, 147, 1197-1212. [CrossRef] [PubMed]

155. Letunic, I.; Bork, P. 20 years of the SMART protein domain annotation resource. Nucleic Acids Res. 2018, 46, D493-D496. [CrossRef] [PubMed]

156. Kelley, L.A.; Mezulis, S.; Yates, C.M.; Wass, M.N.; Sternberg, M.J. The Phyre2 web portal for protein modeling, prediction and analysis. Nat. Protoc. 2015, 10, 845-858. [CrossRef] [PubMed]

157. Henry, J.T.; Crosson, S. Ligand-binding PAS domains in a genomic, cellular, and structural context. Annu. Rev. Microbiol. 2011, 65, 261-286. [CrossRef]

158. Cho, U.S.; Bader, M.W.; Amaya, M.F.; Daley, M.E.; Klevit, R.E.; Miller, S.I.; Xu, W. Metal bridges between the PhoQ sensor domain and the membrane regulate transmembrane signaling. J. Mol. Biol. 2006, 356, 1193-1206. [CrossRef]

159. Gong, W.; Hao, B.; Mansy, S.S.; Gonzalez, G.; Gilles-Gonzalez, M.A.; Chan, M.K. Structure of a biological oxygen sensor: A new mechanism for heme-driven signal transduction. Proc. Natl. Acad. Sci. USA 1998, 95, 15177-15182. [CrossRef]

160. Gerharz, T.; Reinelt, S.; Kaspar, S.; Scapozza, L.; Bott, M. Identification of basic amino acid residues important for citrate binding by the periplasmic receptor domain of the sensor kinase CitA. Biochemistry 2003, 42, 5917-5924. [CrossRef]

161. Kaspar, S.; Perozzo, R.; Reinelt, S.; Meyer, M.; Pfister, K.; Scapozza, L.; Bott, M. The periplasmic domain of the histidine autokinase CitA functions as a highly specific citrate receptor. Mol. Microbiol. 1999, 33, 858-872. [CrossRef]

162. Kneuper, H.; Janausch, I.G.; Vijayan, V.; Zweckstetter, M.; Bock, V.; Griesinger, C.; Unden, G. The nature of the stimulus and of the fumarate binding site of the fumarate sensor DcuS of Escherichia coli. J. Biol. Chem. 2005, 280, 20596-20603. [CrossRef]

163. Pappalardo, L.; Janausch, I.G.; Vijayan, V.; Zientz, E.; Junker, J.; Peti, W.; Zweckstetter, M.; Unden, G.; Griesinger, C. The NMR structure of the sensory domain of the membranous two-component fumarate sensor (histidine protein kinase) DcuS of Escherichia coli. J. Biol. Chem. 2003, 278, 39185-39188. [CrossRef] [PubMed]

164. Reinelt, S.; Hofmann, E.; Gerharz, T.; Bott, M.; Madden, D.R. The structure of the periplasmic ligand-binding domain of the sensor kinase CitA reveals the first extracellular PAS domain. J. Biol. Chem. 2003, 278, 39189-39196. [CrossRef] 
165. Bhate, M.P.; Molnar, K.S.; Goulian, M.; DeGrado, W.F. Signal transduction in histidine kinases: Insights from new structures. Structure 2015, 23, 981-994. [CrossRef] [PubMed]

166. Gushchin, I.; Gordeliy, V. Transmembrane signal transduction in two-component systems: Piston, scissoring, or helical rotation? Bioessays 2018, 40, 1700197. [CrossRef] [PubMed]

167. Maslennikov, I.; Klammt, C.; Hwang, E.; Kefala, G.; Okamura, M.; Esquivies, L.; Mors, K.; Glaubitz, C.; Kwiatkowski, W.; Jeon, Y.H.; et al. Membrane domain structures of three classes of histidine kinase receptors by cell-free expression and rapid NMR analysis. Proc. Natl. Acad. Sci. USA 2010, 107, 10902-10907. [CrossRef]

168. Gushchin, I.; Melnikov, I.; Polovinkin, V.; Ishchenko, A.; Yuzhakova, A.; Buslaev, P.; Bourenkov, G.; Grudinin, S.; Round, E.; Balandin, T.; et al. Mechanism of transmembrane signaling by sensor histidine kinases. Science 2017, 356, eaah6345. [CrossRef]

169. Molnar, K.S.; Bonomi, M.; Pellarin, R.; Clinthorne, G.D.; Gonzalez, G.; Goldberg, S.D.; Goulian, M.; Sali, A.; DeGrado, W.F. Cys-scanning disulfide crosslinking and bayesian modeling probe the transmembrane signaling mechanism of the histidine kinase, PhoQ. Structure 2014, 22, 1239-1251. [CrossRef]

170. Appleman, J.A.; Chen, L.L.; Stewart, V. Probing conservation of HAMP linker structure and signal transduction mechanism through analysis of hybrid sensor kinases. J. Bacteriol. 2003, 185, 4872-4882. [CrossRef]

171. Appleman, J.A.; Stewart, V. Mutational analysis of a conserved signal-transducing element: The HAMP linker of the Escherichia coli nitrate sensor NarX. J. Bacteriol. 2003, 185, 89-97. [CrossRef]

172. Aravind, L.; Ponting, C.P. The cytoplasmic helical linker domain of receptor histidine kinase and methyl-accepting proteins is common to many prokaryotic signalling proteins. FEMS Microbiol. Lett. 1999, 176, 111-116. [CrossRef]

173. Williams, S.B.; Stewart, V. Functional similarities among two-component sensors and methyl-accepting chemotaxis proteins suggest a role for linker region amphipathic helices in transmembrane signal transduction. Mol. Microbiol. 1999, 33, $1093-1102$. [CrossRef]

174. Matamouros, S.; Hager, K.R.; Miller, S.I. HAMP domain rotation and tilting movements associated with signal transduction in the PhoQ sensor kinase. mBio 2015, 6, e00616-15. [CrossRef]

175. Ferris, H.U.; Coles, M.; Lupas, A.N.; Hartmann, M.D. Crystallographic snapshot of the Escherichia coli EnvZ histidine kinase in an active conformation. J. Struct. Biol. 2014, 186, 376-379. [CrossRef]

176. Wang, C.; Sang, J.; Wang, J.; Su, M.; Downey, J.S.; Wu, Q.; Wang, S.; Cai, Y.; Xu, X.; Wu, J.; et al. Mechanistic insights revealed by the crystal structure of a histidine kinase with signal transducer and sensor domains. PLoS Biol. 2013, 11, e1001493. [CrossRef]

177. Dutta, R.; Inouye, M. Reverse phosphotransfer from OmpR to EnvZ in a kinase-/phosphatase+ mutant of EnvZ (EnvZ.N347D), a bifunctional signal transducer of Escherichia coli. J. Biol. Chem. 1996, 271, 1424-1429. [CrossRef] [PubMed]

178. Tomomori, C.; Tanaka, T.; Dutta, R.; Park, H.; Saha, S.K.; Zhu, Y.; Ishima, R.; Liu, D.; Tong, K.I.; Kurokawa, H.; et al. Solution structure of the homodimeric core domain of Escherichia coli histidine kinase EnvZ. Nat. Struct. Biol. 1999, 6, 729-734. [CrossRef] [PubMed]

179. Grebe, T.W.; Stock, J.B. The histidine protein kinase superfamily. Adv. Microb. Physiol. 1999, 41, 139-227. [CrossRef]

180. Wolanin, P.M.; Thomason, P.A.; Stock, J.B. Histidine protein kinases: Key signal transducers outside the animal kingdom. Genome Biol. 2002, 3, REVIEWS3013. [CrossRef] [PubMed]

181. Hsing, W.; Russo, F.D.; Bernd, K.K.; Silhavy, T.J. Mutations that alter the kinase and phosphatase activities of the two-component sensor EnvZ. J. Bacteriol. 1998, 180, 4538-4546. [CrossRef] [PubMed]

182. Podgornaia, A.I.; Casino, P.; Marina, A.; Laub, M.T. Structural basis of a rationally rewired protein-protein interface critical to bacterial signaling. Structure 2013, 21, 1636-1647. [CrossRef] [PubMed]

183. Upton, E.C.; Maciunas, L.J.; Loll, P.J. Vancomycin does not affect the enzymatic activities of purified VanSA. PLoS ONE 2019, 14, e0210627. [CrossRef]

184. Krell, T.; Lacal, J.; Busch, A.; Silva-Jimenez, H.; Guazzaroni, M.E.; Ramos, J.L. Bacterial sensor kinases: Diversity in the recognition of environmental signals. Annu. Rev. Microbiol. 2010, 64, 539-559. [CrossRef] [PubMed]

185. Bergerat, A.; de Massy, B.; Gadelle, D.; Varoutas, P.C.; Nicolas, A.; Forterre, P. An atypical topoisomerase II from Archaea with implications for meiotic recombination. Nature 1997, 386, 414-417. [CrossRef] [PubMed]

186. Dutta, R.; Inouye, M. GHKL, an emergent ATPase/kinase superfamily. Trends Biochem. Sci. 2000, 25, 24-28. [CrossRef]

187. Itou, H.; Tanaka, I. The OmpR-family of proteins: Insight into the tertiary structure and functions of two-component regulator proteins. J. Biochem. 2001, 129, 343-350. [CrossRef] [PubMed]

188. Nguyen, M.P.; Yoon, J.M.; Cho, M.H.; Lee, S.W. Prokaryotic 2-component systems and the OmpR/PhoB superfamily. Can. J. Microbiol. 2015, 61, 799-810. [CrossRef]

189. Gao, R.; Bouillet, S.; Stock, A.M. Structural basis of response regulator function. Annu. Rev. Microbiol. 2019, 73, 175-197. [CrossRef]

190. Maciunas, L.J.; Porter, N.; Lee, P.J.; Gupta, K.; Loll, P.J. Structures of full-length VanR from S. coelicolor in both the inactive and activated states. Acta Crystallogr. D Biol. Crystallogr. 2021, 77, 1027-1039, in press. [CrossRef]

191. Toro-Roman, A.; Wu, T.; Stock, A.M. A common dimerization interface in bacterial response regulators KdpE and TorR. Protein Sci. 2005, 14, 3077-3088. [CrossRef]

192. Martinez-Hackert, E.; Stock, A.M. Structural relationships in the OmpR family of winged-helix transcription factors. J. Mol. Biol. 1997, 269, 301-312. [CrossRef] [PubMed]

193. Depardieu, F.; Podglajen, I.; Leclercq, R.; Collatz, E.; Courvalin, P. Modes and modulations of antibiotic resistance gene expression. Clin. Microbiol. Rev. 2007, 20, 79-114. [CrossRef] [PubMed] 
194. Depardieu, F.; Mejean, V.; Courvalin, P. Competition between VanU(G) repressor and VanR(G) activator leads to rheostatic control of vanG vancomycin resistance operon expression. PLoS Genet. 2015, 11, e1005170. [CrossRef] [PubMed]

195. Narayanan, A.; Kumar, S.; Evrard, A.N.; Paul, L.N.; Yernool, D.A. An asymmetric heterodomain interface stabilizes a response regulator-DNA complex. Nat. Commun. 2014, 5, 3282. [CrossRef]

196. Lou, Y.C.; Weng, T.H.; Li, Y.C.; Kao, Y.F.; Lin, W.F.; Peng, H.L.; Chou, S.H.; Hsiao, C.D.; Chen, C. Structure and dynamics of polymyxin-resistance-associated response regulator PmrA in complex with promoter DNA. Nat. Commun. 2015, 6, 8838. [CrossRef]

197. Friedland, N.; Mack, T.R.; Yu, M.; Hung, L.W.; Terwilliger, T.C.; Waldo, G.S.; Stock, A.M. Domain orientation in the inactive response regulator Mycobacterium tuberculosis MtrA provides a barrier to activation. Biochemistry 2007, 46, 6733-6743. [CrossRef]

198. Nowak, E.; Panjikar, S.; Konarev, P.; Svergun, D.I.; Tucker, P.A. The structural basis of signal transduction for the response regulator PrrA from Mycobacterium tuberculosis. J. Biol. Chem. 2006, 281, 9659-9666. [CrossRef]

199. Robinson, V.L.; Wu, T.; Stock, A.M. Structural analysis of the domain interface in DrrB, a response regulator of the OmpR/PhoB subfamily. J. Bacteriol. 2003, 185, 4186-4194. [CrossRef]

200. Baikalov, I.; Schroder, I.; Kaczor-Grzeskowiak, M.; Grzeskowiak, K.; Gunsalus, R.P.; Dickerson, R.E. Structure of the Escherichia coli response regulator NarL. Biochemistry 1996, 35, 11053-11061. [CrossRef]

201. Maciunas, L.J.; (Department of Biochemistry and Molecular Biology, Drexel University College of Medicine, Philadelphia, PA, USA). Personal communication, 2020.

202. Koteva, K.; Hong, H.J.; Wang, X.D.; Nazi, I.; Hughes, D.; Naldrett, M.J.; Buttner, M.J.; Wright, G.D. A vancomycin photoprobe identifies the histidine kinase VanSsc as a vancomycin receptor. Nat. Chem. Biol. 2010, 6, 327-329. [CrossRef]

203. Lockey, C.; Edwards, R.J.; Roper, D.I.; Dixon, A.M. The extracellular domain of two-component system sensor kinase VanS from Streptomyces coelicolor binds vancomycin at a newly identified binding site. Sci. Rep. 2020, 10, 5727. [CrossRef]

204. Piepenbreier, H.; Diehl, A.; Fritz, G. Minimal exposure of lipid II cycle intermediates triggers cell wall antibiotic resistance. Nat. Commun. 2019, 10, 2733. [CrossRef]

205. Aguilar, P.S.; Hernandez-Arriaga, A.M.; Cybulski, L.E.; Erazo, A.C.; de Mendoza, D. Molecular basis of thermosensing: A two-component signal transduction thermometer in Bacillus subtilis. EMBO J. 2001, 20, 1681-1691. [CrossRef] [PubMed]

206. Braun, Y.; Smirnova, A.V.; Weingart, H.; Schenk, A.; Ullrich, M.S. A temperature-sensing histidine kinase: Function, genetics, and membrane topology. Methods Enzymol. 2007, 423, 222-249. [CrossRef] [PubMed]

207. Storz, G.; Wolf, Y.I.; Ramamurthi, K.S. Small proteins can no longer be ignored. Annu. Rev. Biochem. 2014, 83, 753-777. [CrossRef] [PubMed]

208. Mascher, T. Bacterial (intramembrane-sensing) histidine kinases: Signal transfer rather than stimulus perception. Trends Microbiol. 2014, 22, 559-565. [CrossRef] [PubMed]

209. Jordan, S.; Junker, A.; Helmann, J.D.; Mascher, T. Regulation of LiaRS-dependent gene expression in Bacillus subtilis: Identification of inhibitor proteins, regulator binding sites, and target genes of a conserved cell envelope stress-sensing two-component system. J. Bacteriol. 2006, 188, 5153-5166. [CrossRef] [PubMed]

210. Mascher, T.; Zimmer, S.L.; Smith, T.A.; Helmann, J.D. Antibiotic-inducible promoter regulated by the cell envelope stress-sensing two-component system LiaRS of Bacillus subtilis. Antimicrob. Agents Chemother. 2004, 48, 2888-2896. [CrossRef]

211. Allen, N.E.; Hobbs, J.N., Jr. Induction of vancomycin resistance in Enterococcus faecium by non-glycopeptide antibiotics. FEMS Microbiol. Lett. 1995, 132, 107-114. [CrossRef]

212. Baptista, M.; Depardieu, F.; Courvalin, P.; Arthur, M. Specificity of induction of glycopeptide resistance genes in Enterococcus faecalis. Antimicrob. Agents Chemother. 1996, 40, 2291-2295. [CrossRef]

213. Lai, M.H.; Kirsch, D.R. Induction signals for vancomycin resistance encoded by the vanA gene cluster in Enterococcus faecium. Antimicrob. Agents Chemother. 1996, 40, 1645-1648. [CrossRef]

214. Grissom-Arnold, J.; Alborn, W.E., Jr.; Nicas, T.I.; Jaskunas, S.R. Induction of VanA vancomycin resistance genes in Enterococcus faecalis: Use of a promoter fusion to evaluate glycopeptide and nonglycopeptide induction signals. Microb. Drug Resist. 1997, 3 , 53-64. [CrossRef]

215. Bhardwaj, P.; Ziegler, E.; Palmer, K.L. Chlorhexidine Induces VanA-Type Vancomycin resistance genes in Enterococci. Antimicrob. Agents Chemother. 2016, 60, 2209-2221. [CrossRef]

216. Griffin, J.H.; Linsell, M.S.; Nodwell, M.B.; Chen, Q.; Pace, J.L.; Quast, K.L.; Krause, K.M.; Farrington, L.; Wu, T.X.; Higgins, D.L.; et al. Multivalent drug design. Synthesis and in vitro analysis of an array of vancomycin dimers. J. Am. Chem. Soc. 2003, 125, 6517-6531. [CrossRef]

217. Nakamura, J.; Yamashiro, H.; Hayashi, S.; Yamamoto, M.; Miura, K.; Xu, S.; Doi, T.; Maki, H.; Yoshida, O.; Arimoto, H. Elucidation of the active conformation of vancomycin dimers with antibacterial activity against vancomycin-resistant bacteria. Chemistry 2012, 18, 12681-12689. [CrossRef]

218. Nicolaou, K.C.; Hughes, R.; Cho, S.Y.; Winssinger, N.; Labischinski, H.; Endermann, R. Synthesis and biological evaluation of vancomycin dimers with potent activity against vancomycin-resistant bacteria: Target-accelerated combinatorial synthesis. Chemistry 2001, 7, 3824-3843. [CrossRef]

219. Silverman, S.M.; Moses, J.E.; Sharpless, K.B. Reengineering antibiotics to combat bacterial resistance: Click chemistry [1-3]-triazole vancomycin dimers with potent activity against MRSA and VRE. Chemistry 2017, 23, 79-83. [CrossRef] [PubMed] 
220. Sundram, U.N.; Griffin, J.H. Novel vancomycin dimers with activity against vancomycin-resistant enterococci. J. Am. Chem. Soc. 1996, 118, 13107-13108. [CrossRef]

221. Yarlagadda, V.; Konai, M.M.; Manjunath, G.B.; Ghosh, C.; Haldar, J. Tackling vancomycin-resistant bacteria with 'lipophilicvancomycin-carbohydrate conjugates'. J. Antibiot. 2015, 68, 302-312. [CrossRef] [PubMed]

222. Phillips-Jones, M.K.; Channell, G.; Kelsall, C.J.; Hughes, C.S.; Ashcroft, A.E.; Patching, S.G.; Dinu, V.; Gillis, R.B.; Adams, G.G.; Harding, S.E. Hydrodynamics of the VanA-type VanS histidine kinase: An extended solution conformation and first evidence for interactions with vancomycin. Sci. Rep. 2017, 7, 46180. [CrossRef] [PubMed]

223. Phillips-Jones, M.K.; Lithgo, R.; Dinu, V.; Gillis, R.B.; Harding, J.E.; Adams, G.G.; Harding, S.E. Full hydrodynamic reversibility of the weak dimerization of vancomycin and elucidation of its interaction with VanS monomers at clinical concentration. Sci. Rep. 2017, 7, 12697. [CrossRef]

224. Hughes, C.S.; Longo, E.; Phillips-Jones, M.K.; Hussain, R. Characterisation of the selective binding of antibiotics vancomycin and teicoplanin by the VanS receptor regulating type A vancomycin resistance in the enterococci. Biochim. Biophys. Acta Gen. Subj. 2017, 1861, 1951-1959. [CrossRef]

225. Hussain, R.; Harding, S.E.; Hughes, C.S.; Ma, P.; Patching, S.G.; Edara, S.; Siligardi, G.; Henderson, P.J.; Phillips-Jones, M.K. Purification of bacterial membrane sensor kinases and biophysical methods for determination of their ligand and inhibitor interactions. Biochem. Soc. Trans. 2016, 44, 810-823. [CrossRef] [PubMed]

226. Kwun, M.J.; Novotna, G.; Hesketh, A.R.; Hill, L.; Hong, H.J. In vivo studies suggest that induction of VanS-dependent vancomycin resistance requires binding of the drug to D-Ala-D-Ala termini in the peptidoglycan cell wall. Antimicrob. Agents Chemother. 2013, 57, 4470-4480. [CrossRef] [PubMed]

227. Baptista, M.; Depardieu, F.; Reynolds, P.; Courvalin, P.; Arthur, M. Mutations leading to increased levels of resistance to glycopeptide antibiotics in VanB-type enterococci. Mol. Microbiol. 1997, 25, 93-105. [CrossRef] [PubMed]

228. Baptista, M.; Rodrigues, P.; Depardieu, F.; Courvalin, P.; Arthur, M. Single-cell analysis of glycopeptide resistance gene expression in teicoplanin-resistant mutants of a VanB-type Enterococcus faecalis. Mol. Microbiol. 1999, 32, 17-28. [CrossRef]

229. Cheung, J.; Bingman, C.A.; Reyngold, M.; Hendrickson, W.A.; Waldburger, C.D. Crystal structure of a functional dimer of the PhoQ sensor domain. J. Biol. Chem. 2008, 283, 13762-13770. [CrossRef]

230. Van Bambeke, F.; Chauvel, M.; Reynolds, P.E.; Fraimow, H.S.; Courvalin, P. Vancomycin-dependent Enterococcus faecalis clinical isolates and revertant mutants. Antimicrob. Agents Chemother. 1999, 43, 41-47. [CrossRef]

231. Huynh, T.N.; Stewart, V. Negative control in two-component signal transduction by transmitter phosphatase activity. Mol. Microbiol. 2011, 82, 275-286. [CrossRef]

232. Willett, J.W.; Kirby, J.R. Genetic and biochemical dissection of a HisKA domain identifies residues required exclusively for kinase and phosphatase activities. PLoS Genet. 2012, 8, e1003084. [CrossRef]

233. Lefort, A.; Baptista, M.; Fantin, B.; Depardieu, F.; Arthur, M.; Carbon, C.; Courvalin, P. Two-step acquisition of resistance to the teicoplanin-gentamicin combination by VanB-type Enterococcus faecalis in vitro and in experimental endocarditis. Antimicrob. Agents Chemother. 1999, 43, 476-482. [CrossRef]

234. Depardieu, F.; Courvalin, P.; Msadek, T. A six amino acid deletion, partially overlapping the VanSB G2 ATP-binding motif, leads to constitutive glycopeptide resistance in VanB-type Enterococcus faecium. Mol. Microbiol. 2003, 50, 1069-1083. [CrossRef]

235. Hashimoto, Y.; Tanimoto, K.; Ozawa, Y.; Murata, T.; Ike, Y. Amino acid substitutions in the VanS sensor of the VanA-type vancomycin-resistant Enterococcus strains result in high-level vancomycin resistance and low-level teicoplanin resistance. FEMS Microbiol. Lett. 2000, 185, 247-254. [CrossRef]

236. Pootoolal, J.; Neu, J.; Wright, G.D. Glycopeptide antibiotic resistance. Annu. Rev. Pharmacol. Toxicol. 2002, 42, 381-408. [CrossRef]

237. Xu, L.; Huang, H.; Wei, W.; Zhong, Y.; Tang, B.; Yuan, H.; Zhu, L.; Huang, W.; Ge, M.; Yang, S.; et al. Complete genome sequence and comparative genomic analyses of the vancomycin-producing Amycolatopsis orientalis. BMC Genom. 2014, 15, 363. [CrossRef] [PubMed]

238. Tyson, G.H.; Sabo, J.L.; Rice-Trujillo, C.; Hernandez, J.; McDermott, P.F. Whole-genome sequencing based characterization of antimicrobial resistance in Enterococcus. Pathog. Dis. 2018, 76, fty018. [CrossRef] [PubMed]

239. Zaheer, R.; Cook, S.R.; Barbieri, R.; Goji, N.; Cameron, A.; Petkau, A.; Polo, R.O.; Tymensen, L.; Stamm, C.; Song, J.; et al. Surveillance of Enterococcus spp. reveals distinct species and antimicrobial resistance diversity across a One-Health continuum. Sci. Rep. 2020, 10, 3937. [CrossRef] [PubMed]

240. Kang, Z.Z.; Lei, C.W.; Kong, L.H.; Wang, Y.L.; Ye, X.L.; Ma, B.H.; Wang, X.C.; Li, C.; Zhang, Y.; Wang, H.N. Detection of transferable oxazolidinone resistance determinants in Enterococcus faecalis and Enterococcus faecium of swine origin in Sichuan Province, China. J. Glob. Antimicrob. Resist. 2019, 19, 333-337. [CrossRef]

241. Woods, S.E.; Lieberman, M.T.; Lebreton, F.; Trowel, E.; de la Fuente-Nunez, C.; Dzink-Fox, J.; Gilmore, M.S.; Fox, J.G. Characterization of multi-drug resistant Enterococcus faecalis isolated from cephalic recording chambers in research macaques (Macaca spp.). PLoS ONE 2017, 12, e0169293. [CrossRef] [PubMed]

242. Almeida, L.M.; Lebreton, F.; Gaca, A.; Bispo, P.M.; Saavedra, J.T.; Calumby, R.N.; Grillo, L.M.; Nascimento, T.G.; Filsner, P.H.; Moreno, A.M.; et al. Transferable resistance gene optrA in Enterococcus faecalis from swine in Brazil. Antimicrob. Agents Chemother. 2020, 64, e00142-20. [CrossRef] 
243. Novais, C.; Tedim, A.P.; Lanza, V.F.; Freitas, A.R.; Silveira, E.; Escada, R.; Roberts, A.P.; Al-Haroni, M.; Baquero, F.; Peixe, L.; et al. Co-diversification of Enterococcus faecium core genomes and PBP5: Evidences of pbp5 horizontal transfer. Front. Microbiol. 2016, 7, 1581. [CrossRef]

244. Beukers, A.G.; Zaheer, R.; Goji, N.; Amoako, K.K.; Chaves, A.V.; Ward, M.P.; McAllister, T.A. Comparative genomics of Enterococcus spp. isolated from bovine feces. BMC Microbiol. 2017, 17, 52. [CrossRef] [PubMed]

245. Shiwa, Y.; Yanase, H.; Hirose, Y.; Satomi, S.; Araya-Kojima, T.; Watanabe, S.; Zendo, T.; Chibazakura, T.; Shimizu-Kadota, M.; Yoshikawa, H.; et al. Complete genome sequence of Enterococcus mundtii QU 25, an efficient L-(+)-lactic acid-producing bacterium. DNA Res. 2014, 21, 369-377. [CrossRef]

246. Van Schaik, W.; Top, J.; Riley, D.R.; Boekhorst, J.; Vrijenhoek, J.E.; Schapendonk, C.M.; Hendrickx, A.P.; Nijman, I.J.; Bonten, M.J.; Tettelin, H.; et al. Pyrosequencing-based comparative genome analysis of the nosocomial pathogen Enterococcus faecium and identification of a large transferable pathogenicity island. BMC Genom. 2010, 11, 239. [CrossRef]

247. Hong, H.J.; Hutchings, M.I.; Neu, J.M.; Wright, G.D.; Paget, M.S.; Buttner, M.J. Characterization of an inducible vancomycin resistance system in Streptomyces coelicolor reveals a novel gene (vanK) required for drug resistance. Mol. Microbiol. 2004, 52, 1107-1121. [CrossRef]

248. Yushchuk, O.; Homoniuk, V.; Ostash, B.; Marinelli, F.; Fedorenko, V. Genetic insights into the mechanism of teicoplanin self-resistance in Actinoplanes teichomyceticus. J. Antibiot. 2020, 73, 255-259. [CrossRef] 